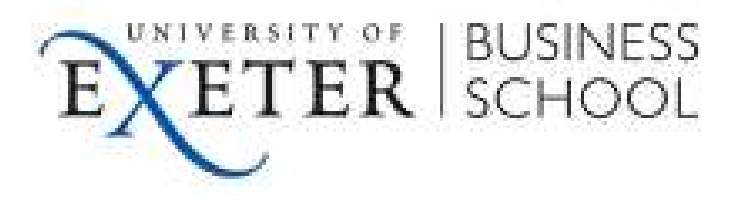

\title{
Stock Market Patterns around Directors' Trades: Effects of Director Category and Gender on Market Timing
}

By

\author{
Alan Gregory, \\ A.Gregory@ex.ac.uk \\ Rajesh Tharyan \\ R.Tharyan@exeter.ac.uk \\ and \\ Ian Tonks \\ I.Tonks@exeter.ac.uk
}

Paper Number: 09/02

First version : September 2007

This version : July 2009

All authors are from the Xfi Centre for Finance and Investment, University of Exeter, Rennes Drive, Exeter, EX4 4ST. This paper has benefited by seminar presentations at the University of Exeter, The British Accounting Association conference, Blackpool April 2008 and the ESRC-CAIR conference, Manchester Business School, May 2008. We are also grateful for comments from Sean Finucane, Emma Jeanes and Grzegorz Trojanowski. Errors remain the responsibility of the authors. 


\title{
Stock market patterns around directors trades: effects of director category and gender on market timing
}

\begin{abstract}
We examine whether directors of UK companies can time the market when they trade in their own-company stock, using a comprehensive dataset on all directors' trades from 1994-2006 for FTSE All Share companies and AIM-listed companies. We find that in the 20 days before a director's buy (sell) trade prices fall (rise) such that abnormal returns are $-2.48 \%(+2.17 \%)$; in the 20 days after a directors' buy (sell) trade, abnormal returns are $1.55 \%(-1.19 \%)$. We go on to examine whether the category (executive or non-executive) and the gender (male or female) of the director differ in the information they posses about their own firms, how they trade on this information and how markets respond to their trades. We test both the information hierarchy hypothesis, that more senior corporate insiders have access to better information, and also a characteristics-based trading hypothesis, that the director's trading pattern depends on the gender of the director. We find some support for the information hierarchy hypothesis, but no difference in the trading patterns and stock market response to directors' gender differences, after conditioning on the category of director.
\end{abstract}

Keywords: Insider trading; director trading, gender JEL classification: G14 


\section{Introduction}

Modern corporate entities are characterized by a separation of ownership and control, and although managers' compensation contracts may include stock incentives to align the interests of shareholders and managers (Baker, Jensen and Murphy, 1998; Murphy, 1999), this raises additional issues when a manager wants to trade in their own company stock. The concern relate to the likely informational asymmetry between the shareholders of the firm, and those managers in control of the day-to-day affairs of the firm, who are privy to private information. These information asymmetries may be exploited by corporate insiders to their own advantage and at the expense of other shareholders. There is ample evidence from Seyhun (1986), Jeng, Metrick and Zeckhauser. (2003), Gregory, Matatko and Tonks (1997), Friederich et al (2002), and Fidrmuc, Goergen and Renneboog (2006) that insiders in UK and US companies do generate abnormal returns when they trade, and this ability of corporate insiders to trade profitably in their company's shares raises concerns over fiduciary duty (Moore, 1990), fairness (Carlton and Fischel, 1983) and efficiency (Leland, 1992) of financial markets. ${ }^{~ . ~}$

In both the US and the UK post-Enron, regulatory concerns implemented through the SarbanesOxley Act in 2002 and the Higgs Report (2003) have emphasized the role of non-executive directors in monitoring the actions of executive directors. However this view of independent non-executive directors relies on these non-executives being different and separate from the executive directors. Fidrmuc et al (2006) test the information hierarchy hypothesis whereby the information content of a directors' trade depends on the category of director making the trade, and find no evidence that returns from trading differ across categories of director. However in their study the four identified categories are: CEOs, Chairman, top-three executives, and other incumbent directors (mainly but not exclusively non-executives). They reject the hypothesis that different categories of directors have differential information. In the current paper, we reexamine the information hierarchy hypothesis, but we focus on only two categories of directors: executive and non-executive, on the basis that this more natural classification

\footnotetext{
${ }^{1}$ Although Lakonishok and Lee (2001) in examining insider trading in companies traded on the NYSE, AMEX, and NASDAQ during the 1975-1995 period find only small stock price responses to the reporting announcement of the trade.
} 
encompasses the idea that executive directors are involved in the day to day management of the company, and have access to more private information than non-executives.

We also study the effect of gender differences on price patterns around directors trading. It is well known that most directors of companies are male, and in Exhibit 1 we report the Female FTSE Index which shows that for both FTSE 100 and FTSE 250 companies there are an average of 11.3 and 8.4 directors per company, respectively, but that females are underrepresented. Even more dramatically, females are more under-represented with respect to executive directorships over non-executive directorships. The ratio of male non-execs to execs is 1.77 , but the ratio of female non-execs to execs is 4.8 . Hence any gender differences in directors' trading, since females are over-represented as non-executive directors relative to executive positions, may contaminate the information hierarchy effect measured only with respect to the category of the director. We therefore examine Seyhun's (1986) information hierarchy hypothesis conditioning on gender, since we note that a greater proportion of nonexecutives than executive directors are female. Hence previous research that has not conditioned on these gender differences, may have erroneously attributed a lack of an information hierarchy effect, because of gender effects. Thus, this paper not only contributes to the literature on insider trading testing both the information hierarchy hypothesis, and a characteristics-based hypothesis of insider trading, but also to the literature in behavioural finance concerning gender biases in trading and investment decisions.

We examine two aspects of price patterns around directors' trades. First we examine whether the two-by-two classification by category (executive or non executive) and gender (male or female) affects the amount or quality of the information that directors posses. We posit that any informational differences will be reflected in the way that directors trade on their personal accounts and the returns they generate: insiders with more information should generate higher abnormal returns from their trades than other insiders. This informed trading is referred to as the ability to time the market. We will examine whether the directors' category or gender matters when assessing the degree of market timing ability. 
The second aspect of directors' trading we consider is the extent of the stock market reaction to the transaction, and whether the response differs depending on the category or the gender of director who is trading. There is evidence that prices fall after a director's sell transaction, and rise after a director's buy transaction. In this context of our two-by-two classification we ask whether markets respond differently to an executive or a non-executive transaction and to a male or a female director's trade. In other words, does the category or gender of the director who is trading matter in determining the market reaction to a director's transaction?

The results of this paper suggest that directors do possess market timing ability in that they buy after a run down in prices and sell after a run up in prices with reversals immediately following the trades. The market views directors' purchases as a more credible signal about a firm's future prospects than directors' sell trades, and this may be because of the markets inability to distinguish between information driven sales and sales for other reasons. We analyze the post event CAARs in a regression framework after controlling for the size, value of shares traded, the number of shares traded as a percentage of holdings, multiple trade dummies and we find that the market reaction to a director's trade is not influenced by the gender of the director but is affected by the category of the director trading.

The paper is organized as follows. Section II provides an outline of the regulatory framework in the UK and Section III summarizes the literature on directors trading and develops the hypotheses to be tested in the current paper. Section IV describes the data and the methodology, and Section V presents the results. Section VI contains various robustness checks and section VII. Concludes.

\section{The regulatory framework and directors' trades in the UK}

In a global examination of insider trading regulations, Bhattacharya and Daouk (2002) report that by the end of 1998, the vast majority of stock markets around the world had insider trading laws. The term insider trading entails the use by a trader of price sensitive information (known to the trader but not to the market as a whole) to trade a financial security to their advantage. Trading by corporate insiders may or may not be based on private information. Trading by corporate insiders is not prohibited in the UK provided the trading does not violate insider 
trading restrictions. Insider trading in the UK is regulated by The Companies Act 1985, The Criminal Justice Act 1993 (Part V), The Financial Services and Markets Act 2000 and the Listing Rules for publicly listed companies on the London Stock Exchange (LSE).

Under the Criminal Justice Act 1993 when a director has inside information acquired by virtue of his/her employment, office or profession, she is prohibited from dealing in any securities that are affected by that information. Inside information, broadly defined, is specific or precise information about particular securities or an issuer that has not been made public and would be likely to have a significant effect on the price of those securities if it were made public. Directors must also not disclose inside information, except in the proper performance of their job. Breach of the Criminal Justice Act is a criminal offence punishable by imprisonment or a fine or both.

The Companies Act 1985 specifies that a director is obliged to disclose to the company any interests in its securities. They must notify the company of all changes in those interests and of dealings connected with them within five business days. The company must keep a register of the interests notified, which must be kept available for inspection. Under the Listing Rules for companies trading on the LSE, the company must notify a Regulatory Information Service (RIS) of interests and changes in those interests before the end of the next business day following receipt of the information from the director. Guidance for companies and directors is available in the Continuing Obligations Guide and the Price Sensitive Information Guide obtained from the Financial Services Authority (FSA). From 15 April 2002 a new mechanism for disseminating regulatory information became effective, allowing listed companies the choice of which Regulatory Information Service to use, to disclose their regulatory information to the market. These RIS providers include: Business Wire Regulatory Disclosure, Newslink Financial, PimsWire, PR Newswire Disclose, and the Regulatory News Service (RNS) provided by the London Stock Exchange.

Listing rules also require that listed companies must have a code of dealing in securities that meets the minimum standards set out in the Model Code. Directors must not deal on considerations of a short-term nature; or during a two-month 'close period' before the 
announcement or publication of the annual report, the half-yearly (or quarterly) results, or when the director is in possession of unpublished price-sensitive information about the company's listed securities; or before receiving clearance from the company chairman or other designated director that the proposed dealing may proceed. The Model Code requirements are more extensive than the prohibitions on insider dealing in the Criminal Justice Act 1993.

The Financial Services and Markets Act 2000 (FSMA) provides the statutory framework for the new UK market abuse regime, which became effective on 1 December 2001. Under the market abuse regime introduced by the FSMA, the FSA can impose penalties on companies or individuals. These may comprise either an appropriate financial penalty or a public censure. The FSA may also apply to the court for injunctions or restitution orders in cases of market abuse. Market abuse is widely defined. It includes behaviour by a person in relation to securities traded on the LSE that amounts to misuse of information; creation of a false or misleading impression; or market distortions.

\section{Literature review and development of hypotheses}

Previous research by Seyhun (1986), Friederich, Gregory, Matatko and Tonks (2002), Hillier and Marshall (2002) and Fidrmuc, Goergen and Renneboog (2006) have identified that corporate insiders time the market when they trade. Directors typically buy after a run down in share prices, and following the insider trade subsequent abnormal returns are positive. Similarly before an insider's sell trade, pre-trade abnormal returns are positive, and share prices then fall after the trade. For example Friederich et al. (2002) using daily data analyse trades by UK directors in mid-cap companies from 1986-1994 and find annualized abnormal returns are a significantly negative $-2.85 \%$ in the 20 days before a purchase, and then for the 20 days after the directors' trade the abnormal returns are a significantly positive $1.96 \%$. They also find that the price patterns are symmetrical for sells, although of smaller magnitude: pre-trade 20-day excess returns are $1.23 \%$ and the excess returns average $-1.46 \%$ for 20 days after the event. Fidrmuc, Goergen and Renneboog (2006) find similar results for directors' trades in UK companies over the period 1991-1998, and also consider the impact of trade size on the CAARS. They find that for both large (trades of at least .01\% of market cap) and small purchases, the trade is preceded by significantly negative CAARS $(-1.27 \%$ and $-2.18 \%)$ and for 
large and small sales (3.07\% and 1.84\%). They conclude that these figures confirm director's market timing abilities.

Seyhun (1986) also suggests an "information hierarchy" hypothesis, based on the idea that an insider's position in the firm affects their access to information. He finds that stock prices are most responsive to the trades of CEOs, then other officers, and finally non-executive directors, and concludes that this supports the information hierarchy hypothesis. Jeng et al (2003) use a performance-evaluation methodology to estimate the returns earned by insiders when they trade their company's stock. They focus on the returns earned by insiders themselves and this differs from the previous event-study methodologies that focus on the informativeness of insider trades for other investors. They find that portfolios formed of stocks with insider purchases earn annualized abnormal returns of more than $6 \%$ per year, but portfolios based on insider sales do not earn significant abnormal returns. Jeng et al also test the information hierarchy hypothesis, and distinguishes between three categories of corporate insiders defined by job-title. The "Topexecutive" portfolio is formed from the trades of those corporate officers that hold the title of chief executive, chairman, or president. The "Other-officers" portfolio includes all corporate officers except for top executives. The third "Directors" portfolio are those non-executive members of the corporate board who do not also hold an officer title. They suggest transactions by top executives are scrutinized by shareholders and regulators, and this may reduce the incentive for the top executive to trade, and hence work against the information hierarchy hypothesis. They find that the portfolios based on the Other-officer-purchase and the Directorpurchase yield point estimates of the abnormal returns that are significant and of similar order of magnitude to the overall purchase portfolio results. In contrast to Seyhun (1986) they find insignificant returns on the top-executive purchase portfolios. However they note that the purchases of the top-executives tend to be twice as large as the other categories, and since they also find that abnormal returns to large purchases are no larger than the returns to mediumsized trades, they are able to reconcile their results with Seyhun's.

Fidrmuc, Goergen and Renneboog (2006) also test for an information hierarchy using the CAARS earned after the trades of the individual categories of directors and a multivariate analysis of the two-day CAR. They look at five categories: CEOs, other executive directors, chairman, other incumbent directors and former directors. However, they find no evidence of 
information hierarchy for the current directors, as the CAARS for the various categories are not significantly different from each other. From the results of the multivariate regressions, they report that the coefficients for all the categories of directors are positive and significant. Interestingly, they find that the CEO purchases $(2.5 \%)$ have the lowest market reaction compared to other officers $(4.9 \%)$, and conclude that this contradicts the information hierarchy hypothesis. They explain their results as due to the fact that CEO transactions are closely monitored and therefore they trade at less informative times compared to other directors. Also, they say that the positive news could be negatively impacted by the fact that when they are purchasing they are also entrenching their positions within the firm, which the market sees as a bad news. They find that the sales transactions also do not lend any support to the information hierarchy hypothesis.

In our work, in contrast to previous studies that have examined the information hierarchy effect by identifying multiple categories of directors and officers of the firm, we consider only the distinction between executive and non-executive members of the board of directors. This is because the many types of executive directors such as the CEO, Finance Director and Operations Director will have different functions within different firms. Bebchuk, Cremers and Peyer (2006) examine the share of CEO pay in all executives' pay for US corporations, and find that this share varies across firms, suggesting that power within corporations is distributed across different executive roles: "CPS [CEO's pay slice] might reflect the relative significance of the CEO in terms of abilities, contribution, or power" (p. 1). This work suggests that to test the information hierarchy hypothesis within the multiple categories of executive directors, one should first condition on the power of the executive within the corporation, possibly proxied by their pay slice. Alternatively, we hypothesize that executive directors as a category will have access to more information than non-executive directors, so that the information hypothesis can be examined with respect to the distinction between executive and non-executive directors.

Recently there has been an increased awareness of the role of the non-executive directors in the management of company affairs, as their effectiveness had been criticized following the Enron and WorldCom scandals (Cheffins and Black, 2006) The literature looking at the relationship between board composition and firm performance has found no concrete evidence of independent directors improving firm's performance. Hermalin and Weisbach (1991), Mehran 
(1995), Klein (1998), Bhagat and Black (2002) all report insignificant relationships between accounting measures of performance and the fraction of independent directors on the board. Aggarwal and Williamson (2006) on the other hand find that the fraction of independent directors in the board has a positive impact on firm's Q in the period between 2001 and 2005. Lin, Pope and Young (2003) examines the stock market reaction to the appointment of nonexecutive directors (NEDs) in UK companies over the period 1993-1996, and finds that the impact of stock market returns depends on the extent of agency problems in the firm and on the monitoring abilities of the NEDs. In cases in which the agency problem is acute, the stock market reaction to the appointment of a NED is positive.

In the UK, the Higgs Report looked at the role of the non-executive director, and as background for this report MORI carried out a survey of company directors. ${ }^{2}$ The survey found that, nearly two-thirds of non-executive directors have never received any training for their role (62\%). Of those who have received training, four in five found it fairly or very useful (81\%). The survey also found that most non-executive directors (81\%) received some sort of briefing or induction when they started their role. But for many, this occurred either before they were appointed or was informal. Only a quarter received a formal induction after appointment (24\%). A quarter of directors think that the largest barrier to the greater effectiveness of non-executive directors is their own lack of time or commitment to the company (25\%). A lack of knowledge/ understanding of the company was cited by one in ten non-executive directors $(10 \%)$ and one in five executive directors (19\%).

The Higgs Report recommended that "To be effective, non-executive directors need to be wellinformed about the company and the external environment in which it operates, with a strong command of issues relevant to the business. A non-executive director should insist on a comprehensive, formal and tailored induction." ${ }^{3}$ On a more anecdotal note, concern on the effectiveness of non-executive directors is reflected in a letter by Warren Buffet to his

\footnotetext{
${ }^{2}$ Interviews with random sample of 605 directors of UK listed companies were conducted by MORI Telephone Surveys (MTS) between 12 August and 18 September 2002. Quotas were set to achieve interviews with 75 chairmen, 250executive directors and 275 non-executive directors and of FTSE 100, FTSE 250 and other listed companies to ensure that the survey sample was broadly representative. Available at http://www.ipsosmori.com/polls/2002/dti-higgs.shtml.

${ }^{3}$ See Annexure C- Guidance for non-executive directors- Higgs Report Page 97.
} 
shareholders, where he comments on independent directors "These people, decent and intelligent though they were, simply did not know enough about business and/or care enough about shareholders to question foolish acquisitions or egregious compensation"

Executive directors typically perform operational and strategic functions and are full-time employees of the firm. While non-executives are not generally involved with the operations of the firm, they are mainly hired for their experience and expertise in specific areas to provide advice and objectivity. Many non-executives work part time and work on specific projects. In terms of the gender composition of corporate boards, though the numbers of women on boards have increased in the last decade, the corporate boardroom remains a predominantly male domain. We hypothesize that the executive directors have more or better quality of information than the non-executive directors and this will be reflected in the abnormal returns they generate from their trades and also in their market timing ability. Thus, in terms of the category of the director, the following hypothesis is stated

HYPOTHESIS 1: Abnormal returns associated with corporate insider trades depend on the category of director making the trade: negative (positive) abnormal returns preceding purchases (sales) and the accompanying positive (negative) abnormal returns following purchases (sales) are larger in absolute value for executive directors than for non-executive directors.

We have already identified in Exhibit 1 that although under-represented on corporate boards, a greater proportion of women are non-executive rather than executive directors. If women trade differently to men, and Barber and Odean, (2001) suggest that there are gender trading differences, it is potentially important to separate out a gender effect from an information hierarchy effect. We will now explore the issue of gender differences in directors' trading patterns, with recourse to the behavioral finance and corporate governance literatures for predictions into these issues. We summarize the evidence over whether a directors' individual characteristics (as proxied by gender) affect their ability to trade on their information (or indeed whether one type is better informed that the other) and how the market will respond to the signal.

\footnotetext{
${ }^{4}$ http://www.berkshirehathaway.com/letters/2002pdf.pdf
} 
There is evidence on gender barriers to senior management positions reported in Oakley (2000), and $\mathrm{Li}$ and Wearing (2002). Cultural and behavioural factors can lead to females being disadvantaged in the managerial labour market: including stereotyping, tokenism and exclusion from networks. Heilman et al. (1989) finds that when male managers were asked to characterize the styles of female managers, they described female managers as less selfconfident, less analytical, and less consistent than male managers. Oakley (2000) notes that in the presence of skewed sex ratios, there is a tendency by the dominant groups to engage in boundary heightening behaviour by which they try to exclude less-dominant groups. Informal (old-boy) networks also have this exclusionary effect by which less powerful males and females are excluded from membership of the informal groups. These same arguments can be adapted to explain that, even if females are appointed to boards of directors in either an executive or non-executive capacity, they may face discrimination in accessing information.

The Female FTSE Index and Report $2006^{5}$ reports that for the FTSE 100 companies the total number of female directorships was $117(10 \%)$ out of which there were $15(4 \%)$ executive directors and 102 (14\%) non-executive directors. The same figures for FTSE 250 firms was $139(6.6 \%), 29(4 \%)$ and $110(8 \%)$ also interestingly they find that for both FTSE 100 and FTSE 250 companies the average board size in companies with female directors was significantly larger than companies with an all-male board. It is possible that, given the small numbers of women on the board that gender barriers persist at board level, that may result in female directors being isolated and hence affecting the quantity or quality of the information they have about the firm.

On the other hand, the female directors who have been appointed to a position on the Board are those who have proved themselves highly able. There is evidence that women directors are as equally qualified as their male counterpart in their professional background, decision-making competency, business and non-business directorships: Burke (2000), McGregor (2000), Sheridan and Milgate (2005) find that both men and women who become members of the board attribute their success to a strong track record, a good understanding of business principles and

\footnotetext{
5 This is the eighth report compiled by Professor Susasn Vinnicombe and Dr Val Singh and published by the Centre for Women Business Leaders, Cranfield University.
} 
their business contacts. However, for women their credibility also needs to be supplemented by high visibility: they note that a women's competence has to be widely acknowledged in the public domain, before nomination committees will consider a woman for a position on the board. Fondas (2000) as cited in Walt and Ingley (2003) concludes that boards with larger proportions of women are more likely to engage in power sharing and influence management decisions.

Carter et al. (2003) examine the relationship between board diversity and firm value for Fortune 1000 firms and provides evidence of a significant positive relation between the proportion of women on the board of directors and firm value. Shrader et al. (1997) however, find that there is a negative relationship between proportion of women on board and firm value. Lee (2007) looks at the stock price reaction to appointment of female CEOs and they find that the announcement of a new female CEO leads to a negative abnormal return of $3.7 \%$ over the announcement window, whereas a new male CEO leads to only a $0.5 \%$ decline in the stock price. They also find that this is less negative when the female directors have been promoted from within the company. They explain that this is because a firm insider provides information about the newcomer, other than gender, and signals to shareholders that the newly appointed CEO has the firm-specific knowledge and experience to lead the organization. Wolfers (2006) examines S\&P 500 firms between 1992-2004 to test whether there are systematic differences in returns to stock of female-headed companies, they conclude with a caveat of low power of their tests, that the null hypothesis that long-run returns of male and female-headed firms are the same cannot be rejected. They conclude that their results show that the markets do not systematically over or underestimate the ability of female CEOs. With respect to the stock market reaction to directors' trades, if the market considers female managers as less skilled and knowledgeable about the firm's affairs, the market will not consider female director trades as an information revealing events, and stock price reaction will be muted.

Studies in behavioral finance have considered various aspects of investors' behaviour ranging from risk taking, trading patterns to ethical decision making. One major difference between men and women is their attitude to risk. Powell and Ansic (1997), Jianakoplos and Bernasek (1998), Schubert, Brown, Gysler, and Brachinger, (1999), Finucane et al. (2000) and Haleck 
and Eisenhauer (2001) all present evidence that women are more risk averse than men in a number of financial decision making contexts. Bruce and Johnson (1994) find that men take larger risks than women do, although they do not find any evidence of differences in performance.

A related gender-based aspect of individuals' characteristics is overconfidence. Lenny (1977), Meehan et al. (1986), and Gervais and Odean (2001) find that men are generally more overconfident in their own abilities than women. Barber and Odean (2001) test the overconfidence model using accounting data for over 35,000 households from a large discount brokerage to analyse the common stock investments of men and women from February 1991 through January 1997. They document that men transact $45 \%$ more than women. They also find that this excessive trading reduces men's net returns by 2.65 percentage points a year as opposed to 1.72 percentage points for women.

An important caveat to these risk-aversion and trading studies is that they are undertaken in relation to the general population and the results may not be directly applicable to our subset of the population who are company directors. Johnson and Powell (1994) compare the decision making characteristics of males and females in "non managerial" positions with those in "managerial" positions and find that for those in managerial positions both genders display similar risk attitudes and make decisions of comparable quality. Atkinson et al. (2003) compare the performance and investment behavior of male and female fixed-income mutual fund managers. They find that male and female managed funds do not differ significantly in terms of performance, risk, and other fund characteristics. Niessen and Ruenzi (2006) arrive at similar conclusions about influence of gender on mutual fund performance.

One further aspect of gender differences, especially relevant in the context of insider trading are attitudes to ethical decision making. Betz et al. (1989) use data from a sample of 213 business school students and finds that men are more than twice as likely as women to engage in actions regarded as unethical. They find that fifty percent of the males were willing to buy stock with insider information. Beams et al. (2003) uses student subjects to test the relationship between the likelihood of trading based on insider information and subjective probabilities of 
deterrents and motivations for insider trading. Expected gain, guilt, cynicism, and fairness of laws were the determinants that had a significant relationship with the intent to transaction based on insider information. Additional findings of the study were that subjects did not view the determinants for themselves in a manner consistent with how they viewed those same deterrents and motivations for other people. With respect to gender differences, the study finds that certainty and social stigma were significantly higher for female respondents than for male respondents. Though student subjects are only a crude proxy for the managerial population, nevertheless, their paper seems to suggest that even if male and female directors may not differ in the information they possess, when and how they trade on this information may differ.

Combining these different aspects of gender differences in relation to directors trading, we formulate our second hypothesis. We would expect female directors to be less likely to exploit market timing opportunities due to lower degrees of risk aversion, lower levels of overconfidence, more ethical behaviour, and exclusion from information in the first place. All of these factors work in the same direction, and consequently we would not expect there to be any pre-trade abnormal returns for female directors' trades. How the market responds to the trade of a female director depends on whether the market believes that the trade is informative or not.

HYPOTHESIS 2: Abnormal returns associated with corporate insider trades depend on the gender of director making the trade: negative (positive) abnormal returns preceding directors' purchases (sales) are smaller in absolute value for females than for males; post-trade positive (negative) abnormal returns following directors' purchases (sales) are smaller in absolute value for female directors than for male directors.

\section{Data and Methodology}

The data on director's dealings for the period $1^{\text {st }}$ January 1994 to $30^{\text {th }}$ September 2006 for UK companies is sourced from the Hemscott directors trading database. This dataset contains information on the trades undertaken by directors (both executive and non-executive), the director's holdings and positions, for all firms listed on the London Stock Exchange. The source dataset contains 374,145 entries pertaining to corporate insider trades (including large shareholders) in 4,412 different firms, and covers all companies that have entered or exited 
since January 1994, and consequently avoids any survivorship biases. We decided to focus on the constituents of the FTSE All Share Index and the companies listed on the Alternative Investment Market (AIM), and so removed trades relating to other companies. To identify the director's gender we use the Price Waterhouse Coopers CD register and the Corporate Register (various issues). We also cross checked our data for FTSE 350 companies with the female FTSE index reports published by the Centre for Women Business Leaders, Cranfield University. Daily returns and daily market capitalizations for the event firms, and the benchmark FTSE All Share Index returns are sourced from Datastream. ${ }^{6}$ The original Hemscott dataset provides information on various transaction types and security types, but we remove trades (option exercise, transfers, take-up of rights) other than open market purchases and sales of ordinary shares by directors. We also removed the transactions of large shareholders.

After cleaning the dataset for duplicate and inaccurate or incomplete transactions, missing announcement dates and transactions dates, summary statistics on the raw data used in this study is presented in Table 1. In this raw dataset there are a total of 80,930 trades by directors over the sample period, divided into 62,106 purchases of company stock and 18,824 sales: so there are three times as many purchases than sales. Trades by male executives constitute the largest group of trades ( $40.3 \%$ of the total number of director trades), with trades by female executives and non-executives being only a small percentage of the total. The average number of times that a director purchases shares is 4.04 over the twelve year sample period, and on average each director sells shares on 2.81 occasions. There is some evidence that male directors trade more than females, but the differences in the average number of trades between executives and non-executives is mixed. The total value of directors' purchases between 1994 and 2006 has been over $£ 3$ billion, but the cumulated total value of sell transactions was almost $£ 11$ billion, making directors net sellers of corporate equity over this period. The average value of a director's purchase was almost $£ 50,000$ but the average value of a sale was over half-amillion pounds: so that directors' sales are fewer in number but much larger in value.

\footnotetext{
${ }^{6}$ The FTSE All share index includes the FTSE100, FTSE250 and the smaller companies. It does not include the fledgling companies or the AIM companies. The directors trading dataset however includes AIM companies.
} 
In order to undertake an event study based on daily data, we need to identify a daily signal for a directors' trade taking into account multiple and possibly conflicting signals when more than one director trades on the same day in the same firm. The standard approach to identifying a daily trading signal is to aggregate the number of shares traded, and define either a buy or sell signal if the net number of trades is positive or negative. However this procedure is inappropriate when multiple directors with multiple characteristics (gender and type) are trading on the same day. Our approach is therefore to construct sub-samples of the raw dataset, in which we then condition on either director category, director gender or both characteristics.

In our analysis of the director's transactions, we work with three subsets of the data. The first subset (Sub-sample 1) conditions on gender, and the second subset (Sub-sample 2) conditions on category. To obtain these first two sub-samples we partition the raw dataset based on the gender (or category) of the director who is trading after eliminating trades on the same day by directors of different genders (or categories) and we then aggregate multiple purchase and sale transactions for each company on the same day to get the sub-samples by gender and category The first subset (Sub-sample 1) is obtained by discarding those firm-days where more than one gender of director is trading. That is, if both a male and a female director are trading in the same stock on the same day, we exclude these observations for that day from Sub-sample 1. Of the remaining firm-days we aggregate the purchases and sales by director gender (either male or female) and define the trading signal based on the net number of shares bought or sold: a buy signal results from positive net trades, and a sell signal from negative net trades. Summary statistics on this subset of the data are provided in Table 2, Panel A. There are a total of 36,129 company-day buy signals, (split between 35,146 male and 983 females) and 10,975 companyday sell signals (split 10,817 males and 158 females), meaning that these are the number of days across time and companies when at least one director traded. If more than one director traded, then to identify whether that company-day observation is a buy or sell signal the number of shares traded is aggregated: a positive net quantity of shares trades represents a buy signal, and a negative net number of shares a sell signal.

Similarly, the second subset (Sub-sample 2) is sorted by the category of the director who is trading (without consideration of gender), and trades by executive and non-executive directors 
on the same firm-days are discarded. The remaining trades are aggregated by category for each firm-day based on the net number of shares traded to obtain buy and sell signals. We use subsamples 1 and 2 to compare abnormal returns around the transactions of male and female directors and those of executive directors and non-executive directors. Summary statistics on Sub-sample 2 are presented in Table 2 Panel B.

However, these two sub-samples are single sorts, that condition on either gender or category. Our third dataset (Sub-sample 3) is a double sort which first sorts by director category and sorts again by gender. We again eliminate transactions where any two directors of the same category or the same gender have traded on the same day and then aggregate the remaining purchases and sales to obtain the daily buy and sell signals. Summary statistics on Sub-sample 3 are presented in Table 2 Panel C.

To investigate the patterns in daily stock prices around directors buys and sell signals, we apply the standard event study methodology based on the market model benchmark ${ }^{7}$. The event day is designated by the announcement date of the director's. There is some disagreement on whether the announcement date or the actual transaction date is should be used as the event date. Hillier and Marshall (2002) note that when a director buys or sell shares, some of the more sophisticated outsiders could be expected to have information on the details of the trade and they define the event date as the transaction date. Fidrmuc et al. (2006) after consultation with practitioners conclude that the use of the announcement date is more appropriate as this is the date when the news of a director's transaction reaches the market.

We consider an event period of -60 to 60 days around the announcement date. The estimation period for the parameters in the market model starts on day -61 and is 250 days in length. We use a standardized cross-sectional t-test and the Corrado rank sum test to test for the significance of the average abnormal returns (AARs) and the cumulative average abnormal

\footnotetext{
${ }^{7}$ We also run the event study using a market adjusted returns model and also using Buy-and-hold abnormal returns (BHAR) as a robustness check and the results are presented in the section: Robustness Checks. The market adjusted returns model calculates the abnormal returns as $A R_{i t}=R_{i t}-R_{m t}$. So the Abnormal return for a security for time $\mathrm{t}$ is simple the observed return for the security (Rit) at time $\mathrm{t}$ minus the observed return on the market index $(R m t)$ at time t.
} 
returns (CAARs). The generalized sign test is used to test the fraction of firms with significantly positive abnormal returns for both single event days and event windows. We also calculate the CAARs for various windows. Boehmer et al. (1991) developed the Standardised cross sectional t-test to address the problem of misspecification due to eventinduced variance changes. With this procedure, the event period residuals are standardized by the estimation period standard deviation and then the average event period standardized residual is divided by its contemporaneous cross-sectional standard error. To tackle the issue of non-normality of abnormal returns, which can cause misspecification in parametric t-tests in event studies (Brown and Warner 1985 and Campbell and Wesley 1993), event clustering, thin trading, increase in the variance of event date abnormal returns (Corrado 1989 and Boehmer, Masumeci, and Poulsen 1991), we employ the corrado rank sum test which is robust to non normal distribution, cross sectional dependence, overlapping sample periods, thin trading and serial dependence in abnormal returns as demostrated by Campbell and Wesley 1993.

\section{Results}

The summary statistics in Tables 1 and 2 provides evidence on the patterns in directors' buy and sell trades by category and gender of directors. Table 1 reports summary numbers on the raw data of directors trades, whereas Table 2 presents summary statistics on the directors' trades aggregated on a daily basis. All of the panels in both tables show that for the raw data and the aggregated data that the number of buy trades is greater than the number of sell trades. However, the mean and the median number of shares, and value of shares traded is larger for sell transactions. On average male directors trade more than female directors, and in slightly larger quantities. Executives and non-executives purchase similar sized amounts, but nonexecutives appear to sell shares in larger quantities. Directors appear to be buying more shares in firms smaller than they sell in. The median firm value for buy trades based on both one-way and two-way classification is smaller for executive directors, non executive directors and male directors. Only the female directors seem to be buying more in larger firms: the mean market value for buy trades are larger for buys than for sells. 
Both the number of shares traded as a percentage of market capitalization and number of shares transacted as a percentage of the directors holding are bigger for director's sells than directors' buys. This is observed for both executives and non-executives and both male and female directors. However, on making the separation by category and gender we find that nonexecutives have higher values of shares traded as a percentage of market capitalization and the number of shares transacted as a percentage of their holding.

The subsequent tables report the stock market abnormal returns for various time-period windows. We first report pre-trade and then in the subsequent tables we report the market reaction post-trade announcement, and also the daily running average daily abnormal (AARS) and average cumulative abnormal returns (AARS and CAARS) for event days from -20 to +20 days around the event. The results in Table 3, are illustrated in Figures 2, 3, 4 and 5 which in summary show that in general, directors tend to buy after a run down in prices and sell after a run up in prices. This is observed both for the one-way (sub-sample 1 and 2) and two-way (sub-sample 3) classifications.

\section{Va Pre-event Market Timing of Directors Trades}

Table 3 Panel A reports that the 20 day cumulative abnormal return prior to the event of the directors' purchase is $-2.48 \%$, meaning that the idiosyncratic fall in a company's stock price averages $2.48 \%$ in the 20 days prior to the announcement of the directors' purchase: directors buy after a significant run down in prices. Restricting the sample to Sub-sample 2, this pattern applies to both executives and non-executives: for executives, the CAAR for all event windows up to the event dates are significantly negative. For $(-20,-1)$ we find that the CAAR are a significant $-2.64 \%$ and for $(-10,-1)$ window a significant $-1.64 \%$. For non-executive directors also, we find significant negative abnormal returns for all the windows. We find that the magnitude of these returns are less than those for executive directors. For $(-20,-1)$ we find that the CAAR are a significant $-1.83 \%$ and for $(-10,-1)$ window a significant $-1.05 \%$. A t-test for the difference of means show that these differences are significant. If we consider the event day returns, for executive and non executive buy transactions, we find that for executives there is consistently significant proportion of transactions with negative returns from around day -12 to -1 . For non executive directors this starts from day -10 and continues until day -1 . The evidence 
suggests that for buy transactions, both categories of director (executive and non-executive) seem to be able to time the market, though the executive directors are better able to time the market than their non-executive counterparts.

Turning to directors' sell trades, there is a symmetric pattern in stock prices movements. In the 20 days prior to the announcement of the sell trade, stock prices rise by $2.17 \%$. For executive directors' sell transactions we find evidence that they sell after a significant run up in prices. We find significant positive returns for all windows. The CAARSs for the $(-20,-1)$ window is $2.01 \%$; and for the $(-10,-1)$ window is $1.20 \%$. For non executive director sell trades we find significant positive returns for all windows. The CAARs for the $(-20,-1)$ window is $2.31 \%$; and for the $(-10,-1)$ window is $1.30 \%$. This is slightly higher than that for executive sells, but both a t-test for difference in means and a rank test show that these are not significantly different. The evidence for sell transactions based on category alone the results seem to suggest that while both categories are able to time the market and that there is no significant differences between the two categories.

Next, we consider classification based on gender of the director, using sub-sample 1 of the dataset. For the male director buy transactions, we find significant CAARs for all event windows. The CAARs for the $(-20,-1)$ period is a significant $-2.50 \%$ and that for the $(-10,-1)$ period is a significant $-1.10 \%$. For female buys, again we find significant negative CAARs for all the event windows. The CAARs for the $(-20,-1)$ period is a significant $-1.74 \%$ and that for the $(-10,-1)$ period is a significant $-1.54 \%$. Both a t-test for a significant difference in means and rank test fail to reject the null hypothesis that there is a significant difference in the mean returns of male and female buy transactions for any of the windows. The event day returns show that for male buys the proportion of transactions earning significant negative abnormal returns start on day -20 and this trend continues consistently until day -3 . However, for female buys we find that the proportion of transactions earning negative abnormal returns is not negative at any time prior to the event date.

For the male sell transactions, the CAARS for the event window $(-20,-1)$ is a significant $2.19 \%$ and that for the window $(-10,-1)$ is significant $1.29 \%$. For female sells, the CAARs for the 
period $(-20,-1)$ is an insignificant $1.14 \%$ and that for $(-10,-1)$ is again an insignificant $0.61 \%$. While the abnormal returns for female sells seem to be smaller than for male sells, a t-test for the difference in means and a rank test show that these differences are not statistically significant. Examining the event day returns we find that for male sells, the proportion of transactions with positive abnormal returns start from day -30 and the trend continues until day -1 . While for female sells, we find that there is no significant proportion of positive abnormal return transactions any time prior to the event date.

In summary the event study results based on a one way classification of directors: either by gender (sub-sample 1) or category (sub-sample 2), shows significant differences only in the case of executive and non executive buy trades. There seems to be no difference between genders for buy or sell trades.

However must bear in mind that executive transactions includes both male executive transactions and female executive transactions and transactions by gender included transactions by both categories of directors, executive and non-executive. In order to separate out the separate effects of category and gender, we carry out a further analysis after a two-way partitioning of the dataset based on category and gender of the director who is trading (subsample 3). These results are presented in Panel B of Table 3.

For the male executive directors buy transactions we find that the CAARs for the $(-20,-1)$ window is a significant $-2.72 \%$ and for $(-10,-1)$ is a significant $-1.69 \%$. Also looking at event day returns the CAARS are significantly negative from about day -44 to day -4 . In addition, the proportions of transactions with significantly negative abnormal returns starts from about day -13 and continue consistently up to day -1 . Therefore, male executive directors display evidence of market timing in their buy transactions. For the male non-executive directors' buy transactions we find there are no significant proportions of negative abnormal return transactions prior to the event date. However, the CAARs are significantly negative from around day -25 relative to the event date right up to day -2 . The CAARs for the window $(-20,-$ 1 ) is a significant $-1.84 \%$ and that for the $(-10,-1)$ window is a significant $-1.04 \%$. 
For female executive directors buy transactions do not find any significant proportion of negative abnormal return transactions in the period prior to the event date. The CAARs for the $(-20,-1)$ window is a significant $-1.36 \%$ and that for $(-10,-1)$ window is a significant $-0.88 \%$. For the female non-executive buy transactions, we find there is no significant proportion of negative abnormal return transactions any time prior to the event window. The CAARs for the $(-20,-1)$ window is a significant $-1.96 \%$ and that for the $(-10,-1)$ window is a significant $-1.23 \%$. Table 3 panel B shows the results of the t-test for difference in means and rank test for the various category and gender buy transactions. We find that for buy transactions the only consistent statistically significant difference is between male executive buys and male nonexecutive buys.

Turning to the directors' sell transactions, for the male executive directors sell transactions we find the proportion of transactions with significant positive abnormal returns start from day -16 and go right up to day -1 . The CAARs for the $(-20,-1)$ window is significant $2.03 \%$ and that for the $(-10,-1)$ window is significant $1.22 \%$. For the male non-executive directors sell transactions we find a significant proportion of transactions having positive abnormal returns starting from around day -21 and going all the way up to day -2 . The CAARs for the window $(-20,-1)$ is a slightly significant $2.29 \%$ and that for the $(-10,-1)$ window is a significant $1.32 \%$.

For the female executive sell transactions, we find that there is no significant proportion of positive abnormal return transactions in the period prior to the event date. The CAARs for the $(-20,-1)$ window is an insignificant $0.54 \%$ and that for the $(-10,-1)$ window is a insignificant $0.10 \%$. For the female non-executive sell transactions, we find no significant proportion of positive abnormal return transactions prior to the event date except on day -2 . The CAARs for the period $(-20,-1)$ is a slightly significant $-2.48 \%$ and the CAARs for the $(-10,-1)$ window is again a slightly significant $1.73 \%$. Table 3 panel B shows the results of the t-test for difference in means and rank test for the various category*gender sell transactions for the various windows. We find that for sell transactions there is no significant difference between any of the various category*gender subgroups for any of the windows. 


\section{Vb Post-event Market Reaction to Directors Trades}

Table 4 Panel A reports that the 20 day cumulative abnormal return after a directors' purchase is on average $1.55 \%$, meaning that in the 20 days after a directors' purchase of shares a company's stock price typically rises on average by $1.55 \%$. Restricting the sample to Subsample 2, this pattern applies to both executives and non-executives: for executive buy transactions we find that the CAARs are a significant $+1.70 \%$ for the $(1,20)$ and $+1.30 \%$ for the $(1,10)$ window. There is an abnormal return of $0.49 \%$ on the announcement day, which cumulates to a $+1.41 \%$ by the 5 th day and to $+1.79 \%$ by the $10^{\text {th }}$ day. For non-executive buys we find that the CAARs are significant and positive for all windows, but the magnitudes are much smaller than for executive buy trades. The CAARs for the $(1,20)$ window and $(1,10)$ window are $+1.18 \%$ and $+0.91 \%$ respectively. The return is a $+0.37 \%$ on the announcement day, which cumulates to a $+1.02 \%$ by the 5 th day and to $+1.27 \%$ by the $10^{\text {th }}$ day. Both t-test and the rank test show that the returns for buy trades are significantly different for all event windows. This seems to suggest that the markets consider the buy trades of executive directors to be more information revealing than that of non-executive directors. We observe that the returns are significantly greater in magnitude but also the speed of the market reaction is faster in the case of executive buys.

For executive sell transactions, the CAARs are significantly negative for all the event windows. CAARs for the $(1,20)$ window and $(1,10)$ window are $-1.22 \%$ and $-0.72 \%$ respectively. The announcement period returns is a $-0.12 \%$ which cumulates to a $-0.53 \%$ by the $5^{\text {th }}$ day and -0.84 by the $10^{\text {th }}$ day. For non-executive sell tranasctions the CAARs are significantly negative for all the event windows. CAARs for the $(1,20)$ window and $(1,10)$ window are $-1.07 \%$ and $0.66 \%$ respectively. The announcement period returns is a $-0.11 \%$ which cumulates to a $-0.38 \%$ by the $5^{\text {th }}$ day and -0.63 by the $10^{\text {th }}$ day. The price reaction seems to be faster for executive sales than for non-executive sales but in terms of magnitude of the reaction there seems to be no statistically significant difference based on the t-test and the rank test.

Based on the gender of the director, we find that for male director buy trades the CAARs are significantly positive for all windows. The CAARs are a significant $+1.57 \%$ for the $(1,20)$ and $+1.22 \%$ for the $(1,10)$ window. There is an abnormal return of $+0.47 \%$ on the announcement 
day, which cumulates to a $+1.34 \%$ by the 5 th day and to $+1.68 \%$ by the $10^{\text {th }}$ day. For female director buy trades the CAARs are $+0.88 \%$ for the $(1,20)$ window and $+0.39 \%$ for the $(1,10)$ window. There is an abnormal return of $+0.42 \%$ on the announcement day, which cumulates to a $+0.82 \%$ by the 5 th day and to $+0.95 \%$ by the $10^{\text {th }}$ day. The result seems to suggest that the price reaction to male directors buy trades seem to be faster and larger than that for female directors. The t-test and rank test confirms that there is a significant difference in the returns of buy trades of the two genders of directors for all the event windows.

For male director sell trades the CAARs are significantly positive for all windows. The CAARs are a significant $-1.20 \%$ for the $(1,20)$ and $-0.73 \%$ for the $(1,10)$ window. There is an abnormal return of $-0.14 \%$ on the announcement day, which cumulates to a $-0.53 \%$ by the 5 th day and to $-0.87 \%$ by the $10^{\text {th }}$ day. For female director sell trades the CAARs are $-0.89 \%$ for the $(1,20)$ window and $-0.60 \%$ for the $(1,10)$ window. There is an insignificant abnormal return of $+0.10 \%$ on the announcement day, which cumulates to a $-0.30 \%$ by the 5 th day and to $-0.50 \%$ by the $10^{\text {th }}$ day. The markets seem to react faster to male director sell signals than female director sell signals, however, the t-test and rank test show that there is no significant difference in the returns of buy trades of the two genders of directors for any of the event windows. Thus in terms of gender, the markets do not seem to value more the sell signals of any one gender of director.

In order to separate out the separate effects of category and gender in the post-trade event study, we now report the results after a two-way partitioning of the dataset based on category and gender of the director who is trading (sub-sample 3). These results are presented in Panel B of Table 4.

Looking first at buy trades, the male executive director's transactions show significant positive abnormal returns for all windows. The CAARs for the $(1,20)$ and $(1,10)$ window are a highly significant $+1.72 \%$ and $1.32 \%$ respectively. The announcement period abnormal return is a $0.49 \%$ which cumulates to $1.42 \%$ by the $5^{\text {th }}$ day and $+1.81 \%$ by the $10^{\text {th }}$ day. For the male nonexecutives again we find significant positive abnormal returns for all windows but the magnitudes are smaller. The CAARs for the $(1,20)$ and $(1,10)$ window are a highly significant 
$+1.22 \%$ and $+0.94 \%$ respectively. The differences are significant for all the event windows. The speed of reaction also is faster for male executive trades than for male non-executive trades.

The female executive director's transactions show significant abnormal returns only for the (1, 10). The CAARs for the $(1,20)$ and $(1,10)$ window are an insignificant $+1.54 \%$ and significant $+1.26 \%$ respectively. The announcement period abnormal return is a $+0.58 \%$ which cumulates to a $1.23 \%$ by the $5^{\text {th }}$ day and $+1.83 \%$ by the $10^{\text {th }}$ day. These are not statistically significantly different from either the male executive abnormal returns or the male non-executive abnormal returns, but they are greater than that for the male non-executive directors. The markets do not seem to react less in the case of female director buy transactions when compared to their male counterparts, but the speed of the reaction is slower. For the female non-executives again we find significant positive abnormal returns for all windows but the magnitudes are smaller. The CAARs for the $(1,20)$ and $(1,10)$ window are an insignificant $+0.52 \%$ and $+0.11 \%$ respectively. The announcement period returns are a insignificant $+0.33 \%$ cumulating to $0.58 \%$ and $0.45 \%$ by the $5^{\text {th }}$ and $10^{\text {th }}$ day.

There is a consistent significant difference is between the executive male buys and non-executive male and non-executive female buys. In addition, we find significant differences in the returns of non-executive male directors and non-executive female directors. Thus taken in total the evidence seems to suggest that market considers the buy trades of executive as a much stronger signal than non-executives and for the non-executive category the signals of male directors are considered much stronger than that of their female counterparts.

Turning to directors' sell trades, the male executive director's transactions show significant negative abnormal returns for all windows. The CAARs for the $(1,20)$ and $(1,10)$ window are a highly significant $-1.24 \%$ and $-0.75 \%$ respectively. The announcement period abnormal return is $-0.13 \%$ which cumulates to a $-0.54 \%$ by the $5^{\text {th }}$ day and $-0.87 \%$ by the $10^{\text {th }}$ day. For the male non-executives again we find significant negative abnormal returns for all windows but the magnitudes are smaller. The CAARs for the $(1,20)$ and $(1,10)$ window are a significant $-1.06 \%$ and $-0.64 \%$ respectively. The announcement period abnormal return is a $-0.17 \%$ which cumulates to a $-0.47 \%$ by the $5^{\text {th }}$ day and $-0.81 \%$ by the $10^{\text {th }}$ day. The differences between male 
executive and male non-executives are not significant for any of the event windows. But the speed of reaction seems to be faster for male executive trades than for male non-executive trades.

The female executive director's transactions do not show significant abnormal returns for any of the event windows. The CAARs for the $(1,20)$ and $(1,10)$ window are an insignificant $-0.31 \%$ and insignificant $+0.16 \%$ respectively. The announcement period abnormal return is a insignificant $+0.04 \%$ which cummulates to a insignificant $+0.25 \%$ by the $5^{\text {th }}$ day and $+0.20 \%$ by the $10^{\text {th }}$ day. For the female non-executives again we find significant negative abnormal returns for all windows. The CAARs for the $(1,20)$ and $(1,10)$ window are a significant $2.18 \%$ and $-2.30 \%$ respectively. The announcement period returns are a insignificant $+0.22 \%$ cumulating to $-1.51 \%$ and $-2.08 \%$ by the $5^{\text {th }}$ and $10^{\text {th }}$ day. However, owing to the small number of transactions for this group, the results may be idiosyncratic.

There is no significant difference between any of the category genders. Therefore taken in total we find that for sale transaction on a finer partitioning of the dataset, the signals do not provide any information to the market.

\section{Ve Multivariate Analysis of CAAR:}

In this section, we conduct a multivariate analysis of the CAAR through the following regression models. We use logarithmic transformations due to the nonlinear relationship between the variables and also because some variables such as market capitalizations exhibit very high values. The two regression models are

CAAR $R_{i . T R A D E}=\alpha+\gamma_{1}$ Mcap $+\gamma_{2}$ Val $+\gamma_{3} \%$ Hold $+\gamma_{4}$ MTDum $+\gamma_{5}$ Cdum $+\gamma_{6}$ GDum $+\mu_{i}$

and

CAAR $_{i, T R A D E}=\alpha+\gamma_{1}$ Mcap $+\gamma_{2}$ Val $+\gamma_{3} \%$ Hold $+\gamma_{4}$ MTDum $+\gamma_{5} V_{1}+\gamma_{6} V_{2}+\gamma_{7} V_{3}+\mu_{i}$

Where the dependent variable is the $C A A R_{i, T R A D E}$ for the " $\mathrm{i}$ "th event, and the TRADE could be either a buy or a sell trade, for the windows $(0,+5)(0,+10)$ and $(0,+20)$. The independent variables are as follows: Mcap is the natural log of the market capitalization of the firm on the event date; Val is natural log of the value of shares traded; \% Hold is natural log of the 
number of shares transacted as a percentage of total holding before the transaction; MTDum is a dummy variable which captures multiple trading on the event date. This represents multiple buys in case of buy transactions and multiple sales in the case of sales transactions; Cdum is a dummy variable which captures the category of the director who trades (i.e. executive or non executive). The category dummy takes a value of 1 if the director is a non-executive director or 0 otherwise; GDum is a dummy variable which captures the gender of the director who trades (i.e. male or female). The gender dummy takes on a value of 1 if the director is a female or 0 otherwise. The second regression equation (2) includes an alternative specification of the gender and category dummy variables: V1, V2 and V3 are dummies to capture the category and gender of the director who trades. V1 is equal to 1 if director is a male non-executive or 0 otherwise. V2 is equal to 1 if the director is a female executive director or 0 otherwise and $\mathrm{V} 3=1$ if the director is a female non-executive or 0 otherwise. The director is an executive male director if $\mathrm{V} 1=\mathrm{V} 2=\mathrm{V} 3=0$.

We check for the correlations between the independent variables and the results are shown in Table 5 Panel A1 and A2. Though we do not find any significant correlations between the variables we also compute the variance inflation factors after the regression. This is shown in Table 6. The estimated parameter coefficients from the regression are reported in Panels B1 and B2 of Table 5. For both the models, for buy transactions the results are very clear. The coefficients for Mcap, Val, \%hold and MTdum all show the expected signs and are significant. The results show that the when directors buy, the trades provide a stronger and more effective signal to the market, the smaller the size of the firm. For small firms in the absence of extensive analyst coverage and a general lack of information regarding these firms, the information that directors trades convey is important. The sign and the significance of the coefficient of Val suggests that the greater the value of shares bought, the stronger the signal is. Similarly we find that the buy signals are stronger when directors are buying more shares as a percentage of their holdings. MTdum is also significant implying that multiple trades convey a stronger signal to the market. The directors' category dummy CDUM is significant while the gender dummy GDUM is not. Thus market reaction does not depend on the gender of the director but rather the category of the director who is trading. 
This becomes clearer still when we look at the results in panel B2 of Table 5, which reports the results of specification (2). Mcap, Val, \%Hold, MTdum are all significant as in Panel B1. Out of V1, V2 and V3 only V1 is significant and the negative sign shows that after controlling for other variables, the only significant difference is between CAARs generated by the trades of Male executive and Male non-executive directors. Thus, the evidence seems to suggest that in terms of market reaction to buy trades, only the category of the director matters and that too only for male directors.

We further test for the linear combinations of the coefficients which represent the returns made by the different category and gender groups after controlling for other factors. The results are show in Table 7 and Table 8 . The results show that all buys have positive abnormal returns while for sells most are not significant. We test whether these are significantly different from each other and we find the significant difference exists only for category not for gender and with in the category executive males seem to elicit better market reaction than non executives

\section{Robustness Checks}

In order to confirm that our results are robust to alternative specifications of the models, we consider two robustness checks

a) Market Adjusted Returns: The choice of the benchmark model is an important determinant of the abnormal returns around the event. We re-run the analysis using market adjusted returns model. The results are presented in table 10. A comparison with Table 4 and Table 5 shows that there is only small quantitative differences between the two methods.

b) Buy-and-Hold Returns: We re-run the analysis computing performance using the buy and hold abnormal returns instead of the cumulative abnormal returns. The results are shown in Table 9. A comparison with Table 4 and Table 5 shows that there is little quantitative difference between the two methods.

\section{Conclusions}

This paper has examined abnormal returns to directors' trades before and after the announcement day using the event study methodology to test whether there is any significant difference in the abilities of a particular category ( i.e. executive or non executive) or gender of 
director (as proxied by gender) to time the market. We also examined whether the market viewed the trades of any particular category or gender of director differently. The event study results seems to suggest, consistent with previous studies that in general directors possess market timing ability in that buy after a run down in prices and sell after a run up in prices with reversals immediately following the trades. The market also seems to view purchase signals as a more credible signals about firms future prospects than sell signals, this is because of the market's inability to distinguish between information driven sales and sales for other reasons. To get a clearer picture, we analysed the post event CAARs after controlling for the size, value of shares traded, the number of shares traded as a percentage of holdings, multiple trade dummies and find that the market reaction to a directors trade is not influenced by the gender of the director but is affected by the category of the director. 


\section{References}

Aggarwal, R., and R.G. Williamson. 2006. Did New Regulations Target the Relevant Corporate Governance Attributes? SSRN eLibrary. http://ssrn.com/paper=859264.

Alexander, K. 2001. Insider Dealing and market Abuse: The Financial Services and Markets Act 2000. ESRC Centre for Business Research, University of Cambridge, Working Paper No 222.

Atkinson, S.M., S.B. Baird, and M.B. Frye. 2003. Do Female Mutual Fund Managers Manage Differently. The Journal of Financial Research 26:1-18.

Bainbridge, S.M. Insider Trading: An Overview. SSRN eLibrary. http://ssrn.com/paper=132529.

Baker, G.P., M.C. Jensen and K.J. Murphy, 1998. Compensation and Incentives: Practice vs. Theory, Journal of Finance, Vol. 63, no. 3, 593-616

Barber, B.M, and T. Odean. 2001. Boys Will be Boys: Gender, Overconfidence, and Common Stock Investment. Quarterly Journal of Economics 116, no. 1: 261-292.

Beams, J. D., R. M. Brown, and L. N. Killough. 2003. An Experiment Testing the Determinants of Non-Compliance with Insider Trading Laws. Journal of Business Ethics 45, no. 4: 309-323.

Bebchuk, L., M. Cremers, and U. Peyer, 2007. Pay Distribution in the Top Executive Team, Harvard John M. Olin Discussion Paper Series: No. 574, 12/2006, Revised 2/07

Beny, L. N.. 2005. Do Insider Trading Laws Matter? Some Preliminary Comparative Evidence. Am Law Econ Rev 7, no. 1 (March 1): 144-183.

Betz, Michael, Lenahan O'Connell, and Jon M. Shepard. 1989. Gender differences in proclivity for unethical behavior. Journal of Business Ethics 8, no. 5 (May 1): 321-324.

Bhagat, S., and B.S. Black. 2002. The Non-Correlation Between Board Independence and Long-Term Firm Performance. Journal of Corporation Law 27:231-273.

Bhattacharya, U, and H. Daouk. 2002. The World Price of Insider Trading. The Journal of Finance 57, no. 1: 75-108.

Boehmer, E., J. Masumeci, and A.B. Poulsen. 1991. Event-study methodology under conditions of event-induced variance. Journal of Financial Economics 30, no. 2 (December): 253-272.

Brown, S.J., and J.B. Warner. 1985. Using daily stock returns: the case of event studies. Journal of Financial Economics 14, no. 1 (March 0): 3-31. 
Bruce, A. C., and J. E. V. Johnson. 1994. Male and female betting behaviour: New perspectives. Journal of Gambling Studies 10, no. 2 (June 1): 183-198.

Burke, R. 2000. Women on Canadian corporate boards: still a long way to go. In R.Burke and M. Mattis (eds) Women On Corporate Boards Of Directors, International Challenges and Opportunities, 97-110. Dordrecht: Kulwer Academic.

Campbell, C.J., and C.E. Wesley. 1993. Measuring security price performance using daily NASDAQ returns. Journal of Financial Economics 33, no. 1 (February): 73-92.

Carlton, D. W., and D. R. Fischel. 1983. The Regulation of Insider Trading. Stanford Law Review 35, no. 5: 857-895.

Carter D.A., Simkins B.J., and Simpson W.G. 2003. Corporate Governance, Board Diversity, and Firm Value. The Financial Review 38:33-53.

Cheffins, B.R., and B.S. Black, 2006. Outside director liability Across Countries, Texas Law Review, Vol. 84, 1385-1480.

Cox, J. D. 1986. Insider Trading and Contracting: A Critical Response to the" Chicago School". Duke Law Journal 1986, no. 4: 628-659.

Fidrmuc, Jana P., Marc Goergen, and Luc Renneboog. 2006. Insider Trading, News Releases, and Ownership Concentration. The Journal of Finance 61, no. 6 (December): 2931-2973.

Finucane M. L., Slovic P., Mertz C.K., Flynn J., and Satterfield T. A. 2000. Gender, race, and perceived risk: the 'white male' effect. Health, Risk \& Society 2:159-172.

Fondas N. 2000. Women on Board of Directors: Gender Bias or Power Threat. In R. Burke and M. Mattis (eds) Women On Corporate Boards Of Directors, 171-177. Netherlands: Kulwer Academic.

Friederich, Sylvain, Alan Gregory, John Matatko, and Ian Tonks. 2002. Short-run Returns around the Trades of Corporate Insiders on the London Stock Exchange. European Financial Management 8, no. 1: 7-30.

Gervais, S, and T Odean. 2001. Learning to be overconfident. Rev. Financ. Stud. 14, no. 1 (January 1): 1-27..

Gregory, Alan, John Matatko, Ian Tonks, and Richard Purkis. 1994. UK Directors' Trading: The Impact of Dealings in Smaller Firms. The Economic Journal 104, no. 422 (January): 37-53.

Halek, Martin, and Joseph G. Eisenhauer (2001) "Demography of Risk Aversion”, The Journal of Risk and Insurance, 68(1), pp.1-24. 
Heilman, Madeline E., Caryn J. Block, Richard F. Martell, and Michael C. Simon. 1989. Has Anything Changed? Current Characterizations of Men, Women, and Managers. Journal of Applied Psychology 74, no. 6 (December): 935.

Hermalin, Benjamin E., and Michael S. Weisbach. 1991. The Effects of Board Composition and Direct Incentives on Firm Performance. Financial Management 20, no. 4 (Winter): 101112.

Higgs, D., 2003, "Review of the role and effectiveness of non-executive directors", Department of Trade and Industry Report.

Hillier, D., and A. P. Marshall. 2002. The Market Evaluation of Information in Directors' Trades. Journal of Business Finance \& Accounting 29, no. 1 \& 2: 77-110.

Jeng, Leslie A, Andrew Metrick, and Richard Zeckhauser. 2003. Estimating the Returns to Insider Trading: A Performance-Evaluation Perspective. Review of Economics and Statistics 85, no. 2: 453-471.

Jensen, Michael C., and William H. Meckling. 1976. Theory of the firm: Managerial behavior, agency costs and ownership structure. Journal of Financial Economics 3, no. 4 (October): 305360.

Jianakoplos, N.A. and Bernasek, A. (1998) “Are Women More Risk Averse?"

Economic Enquiry, 36, pp.620-630.

Johnson, J. E.V, and P. L Powell. 1994. Decision Making, Risk and Gender: Are Managers Different? British Journal of Management 5, no. 2: 123-138.

Kahle K.M.. 2000. Insider trading and the long-run performance of new security issues. Journal of Corporate Finance 6:25-53.

Ke B., Huddart S., and Petroni K. 2003. What insiders know about future earnings and how they use it: Evidence from insider trades. Journal of Accounting and Economics 35:315-346.

King, M., and A. Roell. 1988. Insider Trading. Economic Policy 3, no. 6 (April): 163-193.

Klein, A., 1998. Firm Performance and Board Committee Structure. Journal of Law and Economics 41, no. 1 (April): 275-303.

Klock M. 1994, Mainstream Economics and the Case for Prohibiting Insider Trading. Georgia State University Law Review 297.

Kraakman R. 1991, The Legal Theory of Insider Trading Regulation in the United States. In European Insider Dealing, ed. K Hopt and E Wymeersch. 
Lakonishok, J., and I. Lee. 2001, Are insider trades informative? Review of Financial Studies 14, no. 1 (January 1): 79-11..

Leland, H. (1992) "Insider trading: Should it be prohibited?", Journal of Political Economy, vol. 100 , no. $4,859-887$

Lenny, E. 1977. Women's self-confidence in achievement settings. Psychological Bulletin 84:113.

Li, C., and R. Wearing. 2002. Between glass ceilings: Female Non-executive Directors in UK Quoted Companies. Working Paper.

Lin, J-C, and J.S. Howe. 1990. Insider Trading in the OTC Market. The Journal of Finance 45, no. 4: 1273-1284.

Lin, S., P.F. Pope and S. Young, 2003, Stock Market Reaction to the Appointment of Outside Directors, Journal of Business Finance and Accounting, vol. 30 no. 3/4, 351-382.

Manne, H. G. 1966. Insider trading and the stock market. Collier-Macmillan.

McGregor, J. 2000. The New Zealand experiment - training to be on board as a director. In $R$. Burke and M. Mattis (eds) Women On Corporate Boards Of Directors, International Challenges and Opportunities, 129-144. Dordrecht: Kulwer Academic.

Meehan, Anita M., and Overton, Willis F. 1986. Gender Differences in Expectancies for Success and Performance on Piagetian Spatial Tasks. Merrill-Palmer Quarterly 32, no. 4 (October): 427-441.

Mehran , Hamid. 1995. Executive compensation structure, ownership, and firm performance. Journal of Financial Economics 38:163-184.

Moore, Journal of Business Ethics, 1990,

Murphy, K. 1999, Executive Compensation. in: O.Ashenfelter and D. Card.(eds) Handbook of Labour Economics, vol.3. Amsterdam: North Holland. p. 2485-2563.

Niessen, A., and S. Ruenzi, 2006, Sex matters: gender and mutual funds. Working paper, University of Cologne and Centre for Financial Research Cologne, Cologne..

Oakley J.G. 2000, Gender-based Barriers to Senior Management Positions: Understanding the Scarcity of Female CEOs. Journal of Business Ethics 27:321-334.

Lee, P.M., and E.H.J. James. 2007, She'-e-os: gender effects and investor reactions to the announcements of top executive appointments. Strategic Management Journal 28, no. 3: 227241. 
Pope, P. F., R. C. Morris, and D. A. Peel. 1990, Insider Trading: Some Evidence on Market Efficiency and Directors' Share Dealings in Great Britain. Journal of Business Finance and Accounting 17, no. 3: 359-380.

Powell, M. and D. Ansic, 1997, Gender Differences in Risk Behavior in Financial DecisionMaking: An Experimental Analysis, Journal of Economic Psychology, 18 (6), 605-28.

Rozeff, M.S., and M.A. Zaman. 1998, Overreaction and Insider Trading: Evidence from Growth and Value Portfolios. The Journal of Finance 53, no. 2 (April): 701-716.

Sarbanes-Oxley (2002)

Schubert, R., M. Brown, M. Gysler, and H.W. Brachinger, 1999, Financial Decision-Making: Are Women Really More Risk Averse?", American Economic Review, papers and Proceedings, 89(2), pp.381-385.

Seyhun, H. N., 1986, Insiders' profits, costs of trading, and market efficiency. Journal of Financial Economics 16, no. 2: 189-212.

Sheridan, A. and G. Milgate. 2005, Accessing Board Positions: a comparison of female and male board members views. Corporate Governance 13:847-855.

Shrader, C.B., V.B. Blackburn, and P. Iles. 1997, Women in Management and Firm Financial Performance: An Exploratory Study. Journal of Managerial Issues 9:355-372.

Walt N., and Ingley C. 2003, Board Dynamics and the Influence of Professional Background, Gender and Ethnic Diversity of Directors. Corporate Governance 11:218-234.

Wolfers, J., 2006, Diagnosing Discrimination: Stock Returns and CEO Gender. Journal of the European Economic Association 4, no. 2-3: 531-541. 
Figure 1: Average Size and Composition of UK Boards of Directors in 2006 by Category and Gender

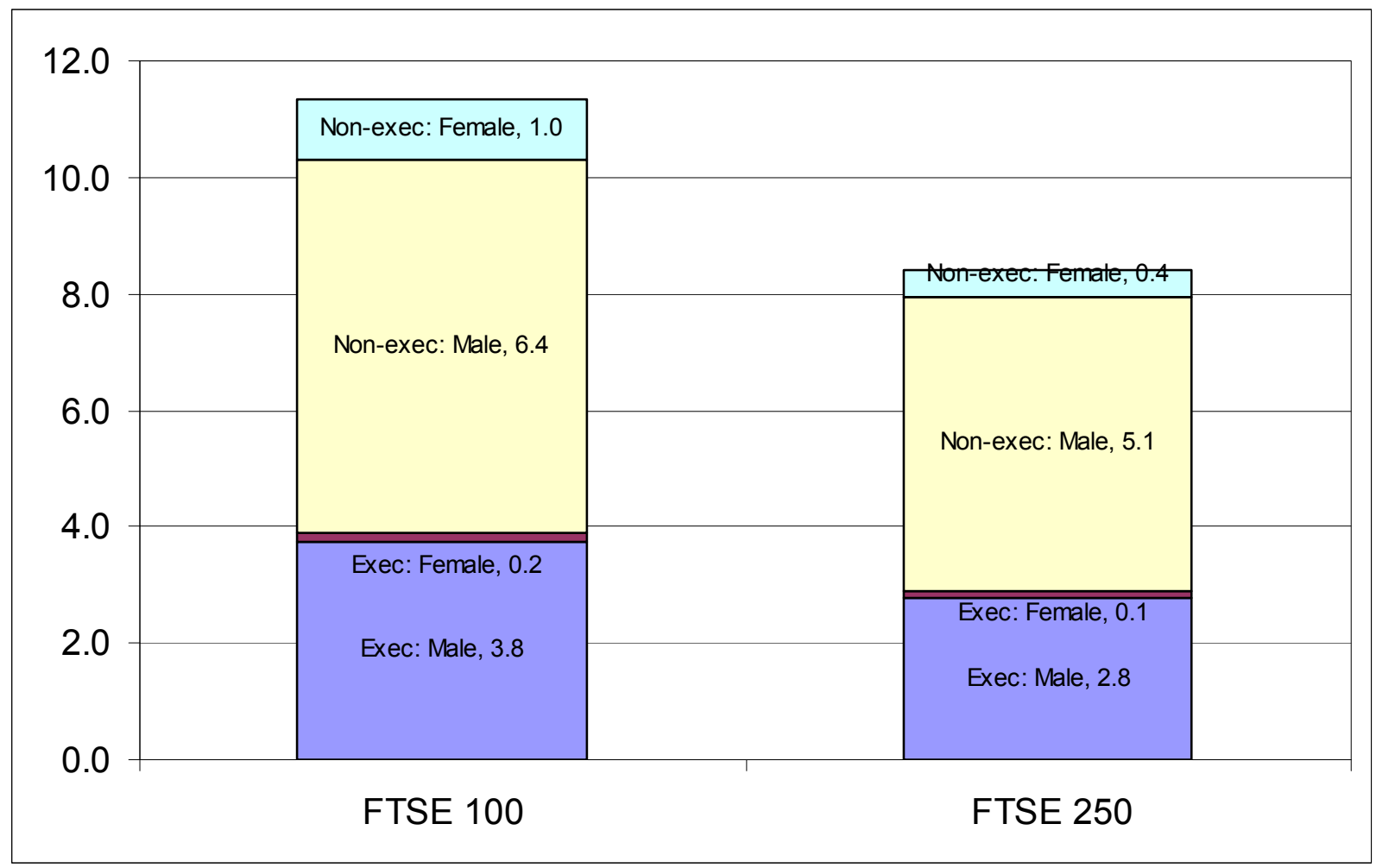

\begin{tabular}{|c|c|c|c|c|c|c|c|c|c|}
\hline & \multicolumn{3}{|c|}{ FTSE 100 } & \multicolumn{3}{c|}{ FTSE 250 } & \multicolumn{3}{c|}{ FTSE 350 } \\
\hline & E & Non-E & Total & E & Non-E & Total & E & Non-E & Total \\
\hline Male & 376 & 641 & 1,017 & 696 & 1,265 & 1,961 & 1,072 & 1,906 & 2,978 \\
\hline Female & 15 & 102 & 117 & 29 & 110 & 139 & 44 & 212 & 256 \\
\hline Total & 391 & 743 & 1,134 & 725 & 1,375 & 2,100 & 1,116 & 2,118 & 3,234 \\
\hline
\end{tabular}

Source: Female FTSE Index and Report 2006, Published by the Cranfield International Centre for Women Business Leaders, Cranfield University. 

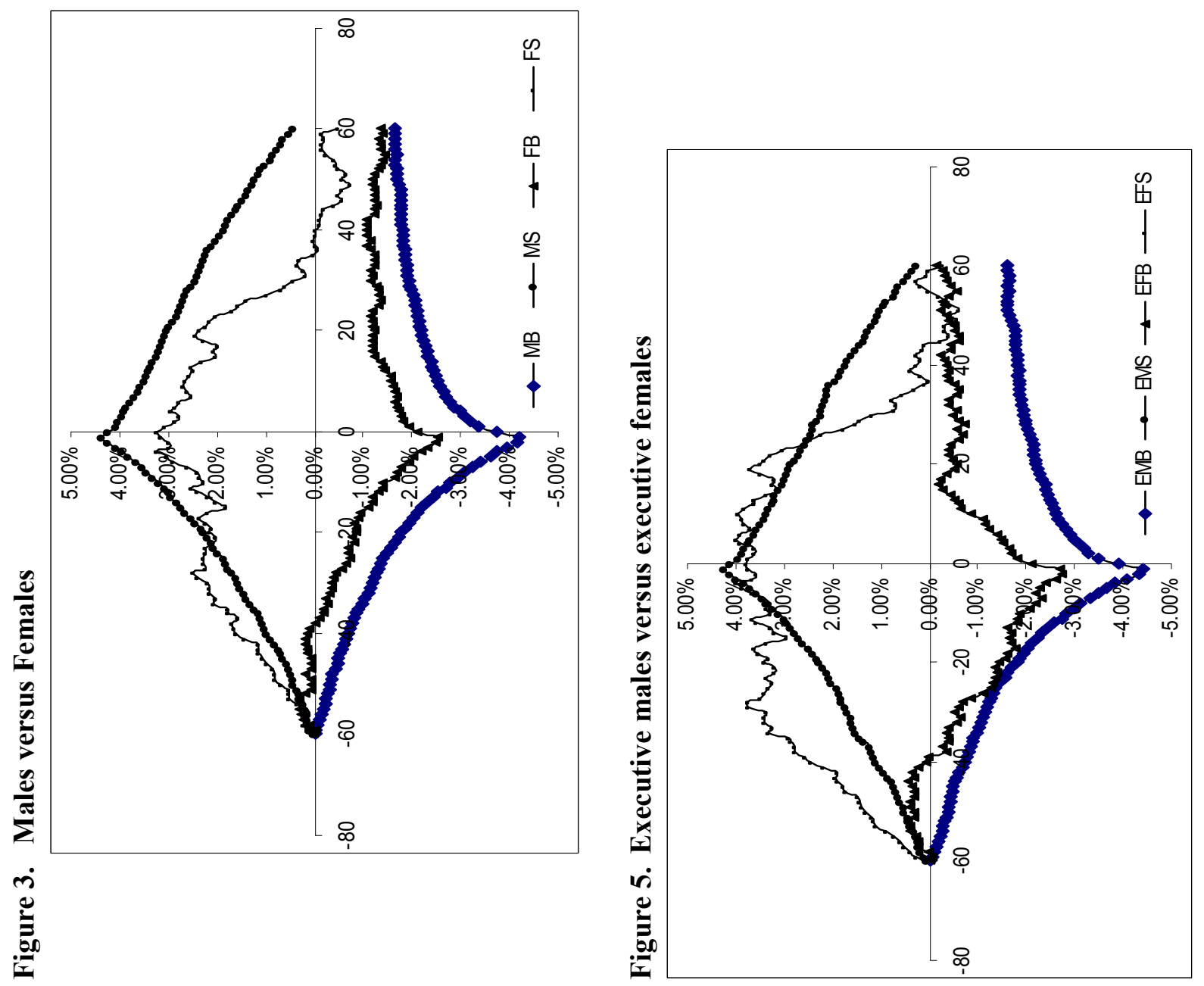

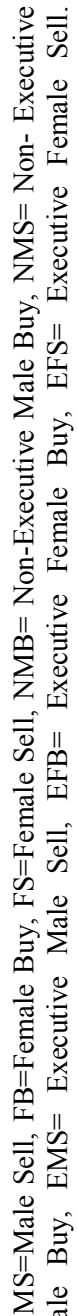

$\hat{n}$

离

为

空

돋ㄷㄴ

市

发

乙:

作

ติ

䎡

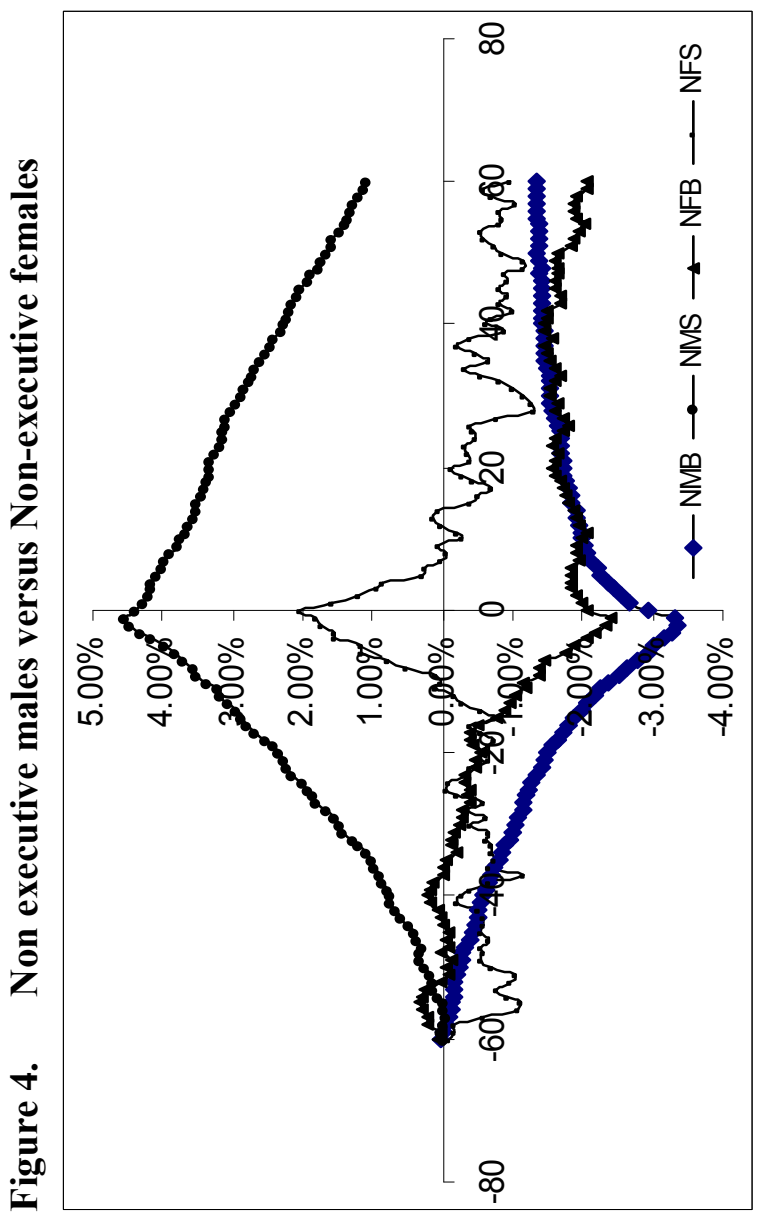

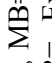

矛部

言

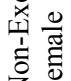

Z I

式.

空离

艺

戓的

产

至孚

艺

?

प्रू.

넘ํㄹ

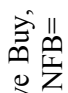

害示

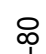




\section{Table 1. Descriptive Statistics: Raw Data}

Table 1 reports the transaction type, number of trades over the sample, number of directors trading, average number of trades per director, the total value of all trades and the average value of a single trade of all directors and broken down by category and gender. This table is based on the raw dataset, before aggregating the daily buy and sell signals. $\mathrm{F}=$ female, $\mathrm{M}=\mathrm{Male}$; $\mathrm{P}=\mathrm{Purchases}$ and $\mathrm{S}=$ sales.

\begin{tabular}{|c|c|c|c|c|c|c|c|c|}
\hline Trade Type & $\begin{array}{l}\text { Director } \\
\text { Category }\end{array}$ & $\begin{array}{l}\text { Director } \\
\text { Gender }\end{array}$ & $\begin{array}{l}\text { No of } \\
\text { Trades }\end{array}$ & $\begin{array}{l}\text { Percent } \\
\text { of Total } \\
\text { trades }\end{array}$ & $\begin{array}{c}\text { No of } \\
\text { Directors }\end{array}$ & $\begin{array}{c}\text { Average } \\
\text { Number } \\
\text { of trades } \\
\text { per } \\
\text { director }\end{array}$ & $\begin{array}{c}\text { Total } \\
\text { Value of } \\
\text { all trades } \\
(£ \\
\text { million) }\end{array}$ & $\begin{array}{c}\text { Average } \\
\text { value of a } \\
\text { trade }(£)\end{array}$ \\
\hline Purchases & & & 62,106 & 76.74 & 15,357 & 4.04 & 3,094 & 49,821 \\
\hline $\mathrm{P}$ & Exec & M & 32,613 & 40.30 & 8,276 & 3.94 & 1,460 & 44,767 \\
\hline$P$ & Exec & $\mathrm{F}$ & 1,038 & 1.28 & 274 & 3.79 & 21 & 20,091 \\
\hline$P$ & Non-exec & $M$ & 27,324 & 33.76 & 6,471 & 4.22 & 1,570 & 57,459 \\
\hline $\mathrm{P}$ & Non-exec & $\mathrm{F}$ & 1,131 & 1.40 & 336 & 3.37 & 43 & 38,285 \\
\hline Sales & & & 18,824 & 23.26 & 6,689 & 2.81 & 10,913 & 579,717 \\
\hline$S$ & Exec & $M$ & 12,421 & 15.35 & 4,344 & 2.86 & 6,320 & 508,816 \\
\hline$S$ & Exec & $\mathrm{F}$ & 260 & 0.32 & 119 & 2.18 & 127 & 488,462 \\
\hline$S$ & Non-exec & $M$ & 6,038 & 7.46 & 2,173 & 2.78 & 4,320 & 715,469 \\
\hline S & Non-exec & $\mathrm{F}$ & 105 & 0.13 & 53 & 1.98 & 146 & $1,386,667$ \\
\hline Total Trades & & & 80,930 & 100.00 & & & 14,007 & 173,072 \\
\hline
\end{tabular}


Table 2. Descriptive Statistics: Sub-samples of Daily Trading Signals

This table reports the descriptive statistics on the four sub-samples of data constructed from the raw data after aggregating over daily trades to obtain daily trading signals.

\begin{tabular}{|c|c|c|c|c|c|c|c|c|c|}
\hline \multirow[t]{2}{*}{ Panel A: Sub-sample 1} & & \multicolumn{3}{|c|}{ Buy Sample } & \multicolumn{3}{|c|}{ Sell Sample } & & \\
\hline & & $\begin{array}{c}\text { All } \\
\text { Directors }\end{array}$ & Male & Female & $\begin{array}{c}\text { All } \\
\text { directors }\end{array}$ & Male & Female & & \\
\hline Number of Daily Signals & & 36,129 & 35,146 & 983 & 10,975 & 10,817 & 158 & & \\
\hline \multirow[t]{2}{*}{ Market Value of firms ( $£$ million): } & Mean & 1,918 & 1,872 & 3,580 & 1,746 & 1,754 & 1,189 & & \\
\hline & Median & 108 & 104 & 278 & 158 & 158 & 140 & & \\
\hline \multirow[t]{2}{*}{ Value of Shares Traded $(£)$ : } & Mean & 49,425 & 77,209 & 27,538 & 566,472 & 909,560 & 303,730 & & \\
\hline & Median & 8,505 & 10,530 & 6,650 & 42,165 & 63,000 & 28,882 & & \\
\hline \multirow[t]{2}{*}{$\%$ of Holdings Traded: } & Mean & 31.15 & 67.26 & 53.97 & 0.20 & 20.00 & 27.00 & & \\
\hline & Median & 13.12 & 16.86 & 44.83 & 0.09 & 9.00 & 13.00 & & \\
\hline \multirow[t]{2}{*}{ Trade value as $\%$ of market cap: } & Mean & 1.94 & 0.20 & 0.06 & 7.57 & 0.76 & 0.39 & & \\
\hline & Median & 0.10 & 0.01 & 0.00 & 0.46 & 0.05 & 0.03 & & \\
\hline \multirow[t]{2}{*}{ Panel B: Sub-sample 2} & & \multicolumn{2}{|c|}{ Buy Sample } & \multicolumn{2}{|c|}{ Sell Sample } & & & & \\
\hline & & Exec & Non-Exec & Exec & $\begin{array}{l}\text { Non- } \\
\text { Exec } \\
\end{array}$ & & & & \\
\hline Number of Signals & & 16,275 & 17,386 & 6,761 & 3,417 & & & & \\
\hline \multirow[t]{2}{*}{ Market Value of firms ( $£$ million): } & Mean & 2,458 & 1,588 & 2,139 & 1,182 & & & & \\
\hline & Median & 111 & 116 & 178 & 131 & & & & \\
\hline \multirow[t]{2}{*}{ Value of Shares Traded $(\mathfrak{£})$ : } & Mean & 60,963 & 73,340 & 603,568 & 824,869 & & & & \\
\hline & Median & 9,600 & 10,002 & 55,700 & 58,028 & & & & \\
\hline \multirow[t]{2}{*}{$\%$ of Holdings Traded: } & Mean & 46.87 & 53.24 & 19.00 & 24.00 & & & & \\
\hline & Median & 8.72 & 26.86 & 9.00 & 11.00 & & & & \\
\hline \multirow[t]{2}{*}{ Trade value as $\%$ of market cap: } & Mean & 0.15 & 0.16 & 0.49 & 0.53 & & & & \\
\hline & Median & 0.01 & 0.01 & 0.03 & 0.06 & & & & \\
\hline \multirow[t]{2}{*}{ Panel C: Sub-sample 3} & & \multicolumn{4}{|c|}{ Buy Sample } & \multicolumn{4}{|c|}{ Sell Sample } \\
\hline & & ME & MNE & FE & FNE & ME & MNE & FE & FNE \\
\hline Number of Signals & & 15,565 & 16,579 & 359 & 622 & 6,578 & 3,375 & 110 & 48 \\
\hline \multirow[t]{2}{*}{ Market Value of firms ( $£$ million): } & Mean & 2,478 & 1,402 & 2,047 & 4,442 & 2,171 & 1,166 & 740 & 2,219 \\
\hline & Median & 111 & 108 & 207 & 388 & 179 & 130 & 121 & 214 \\
\hline \multirow[t]{2}{*}{ Value of Shares Traded $(£)$ : } & Mean & 61,423 & 73,863 & 15,542 & 34,542 & 600,820 & 834,820 & 334,430 & 233,360 \\
\hline & Median & 9,750 & 10,046 & 3,000 & 7,925 & 55,426 & 58,500 & 39,150 & 19,805 \\
\hline \multirow[t]{2}{*}{$\%$ of Holdings Traded: } & Mean & 45.10 & 50.40 & 37.55 & 63.57 & 19.00 & 24.00 & 25.00 & 30.37 \\
\hline & Median & 8.81 & 25.00 & 5.80 & 73.94 & 9.00 & 11.00 & 11.00 & 19.80 \\
\hline \multirow[t]{2}{*}{ Trade value as $\%$ of market cap: } & Mean & 0.15 & 0.16 & 0.04 & 0.07 & 0.48 & 0.54 & 0.51 & 0.12 \\
\hline & Median & 0.01 & 0.01 & 0.00 & 0.00 & 0.03 & 0.06 & 0.04 & 0.01 \\
\hline
\end{tabular}


Table 3. Reports the results of the event studies for the various pre-event windows. Panel A reports the results for the results based on the category of the director. Panel B reports the results of the event study on subsamples formed on the basis of category and gender of the director. Panel B1 reports the results of the pairwise test for difference in CAARS between the various subgroups. The $\mathrm{t}$ and $\mathrm{z}$ are the statistics from a t-test and a wilcoxon rank sum test respecively. In Panel B1, EM=Male Executive, NM=Male Non-Executive, EF=Female Executive, $\mathrm{NF}=\mathrm{Female}$ Non executive. The symbols $\$, *, * *$, and $* * *$ denote statistical significance at the $0.10,0.05,0.01$ and 0.001 levels, respectively, using a 2 -tailed standardised cross sectional test.

Panel A

\begin{tabular}{|l|c|c|c|c|c|c|c|c|}
\hline Marktet Model & \multicolumn{9}{|c|}{ Buy } & \multicolumn{4}{c|}{ Sell } \\
\hline Director & $\mathbf{( - 2 0 , - 1 )}$ & $\mathbf{( - 1 0 , - 1 )}$ & $\mathbf{( - 5 , - 1 )}$ & $\mathbf{( - 1 , 0 )}$ & $\mathbf{( - 2 0 , - 1 )}$ & $\mathbf{( - 1 0 , - 1 )}$ & $\mathbf{( - 5 , - 1 )}$ & $\mathbf{( - 1 , 0 )}$ \\
\hline All Directors & $-2.48 \%^{* * *}$ & $-1.52 \%^{* * *}$ & $-0.78 \%^{* * *}$ & $0.42 \%^{* * *}$ & $2.17 \%^{* * *}$ & $1.28 \%^{* * *}$ & $0.69 \%^{* * *}$ & $-0.02 \%^{* * *}$ \\
\hline Executive & $-2.64 \%^{* * *}$ & $-1.64 \%^{* * *}$ & $-0.9 \%^{* * *}$ & $0.41 \%^{* * *}$ & $2.01 \%^{* * *}$ & $1.20 \%^{* * *}$ & $0.63 \%^{* * *}$ & $-0.02 \%^{* *}$ \\
\hline Non Executive & $-1.83 \%^{* * *}$ & $-1.05 \%^{* * *}$ & $-0.4 \%^{* * *}$ & $0.41 \%^{* * *}$ & $2.31 \%^{* * *}$ & $1.33 \%^{* * *}$ & $0.72 \%^{* * *}$ & $-0.07 \%^{*}$ \\
\hline t- test for diff & -5.33 & -5.26 & -5.98 & 0.003 & -1.32 & -0.82 & -0.79 & 0.77 \\
\hline Rank test for diff & -5.69 & -5.65 & -5.94 & 1.45 & -1.20 & -0.42 & -0.41 & 0.71 \\
\hline & & & & & & & & \\
\hline Male & $-2.5 \%^{* * *}$ & $-1.10 \%^{* * *}$ & $-0.59 \%^{* * *}$ & $0.42 \%^{* * *}$ & $2.19 \%^{* * *}$ & $1.29 \%^{* * *}$ & $0.69 \%^{* * *}$ & $-0.02 \%$ \\
\hline Female & $-1.74 \%^{* * *}$ & $-1.54 \%^{* * *}$ & $-0.79 \%^{* * *}$ & $0.39 \%^{* *}$ & $1.14 \%$ & $0.61 \%$ & $0.26 \%$ & $0.24 \%$ \\
\hline$t$-test for diff & 1.93 & 1.46 & 0.98 & -0.28 & -1.12 & -1.03 & -0.94 & 1.13 \\
\hline Rank test for diff & 1.41 & 1.72 & -0.132 & -0.88 & -1.18 & -0.54 & -0.811 & 0.54 \\
\hline
\end{tabular}

Panel B

\begin{tabular}{|l|c|c|c|c|c|c|c|c|}
\hline Marktet Model & \multicolumn{4}{|c|}{ Buy } & \multicolumn{4}{c|}{ Sell } \\
\hline Director & $\mathbf{( - 2 0 , - 1 )}$ & $\mathbf{( - 1 0 , - 1 )}$ & $\mathbf{( - 5 , - 1 )}$ & $\mathbf{( - 1 , 0 )}$ & $\mathbf{( - 2 0 , - 1 )}$ & $\mathbf{( - 1 0 , - 1 )}$ & $\mathbf{( - 5 , - 1 )}$ & $\mathbf{( - 1 , 0 )}$ \\
\hline Male Executive & $-2.72 \%^{* * *}$ & $-1.69 \%^{* * *}$ & $-0.93 \%^{* * *}$ & $0.40 \%^{* * *}$ & $2.03 \%^{* * *}$ & $1.22 \%^{* * *}$ & $0.64 \%^{* * *}$ & $-0.02 \%$ \\
\hline Male Non-executive & $-1.84 \%^{* * *}$ & $-1.04 \%^{* * *}$ & $-0.3 \%^{* * *}$ & $0.41 \%^{* * *}$ & $2.29 \%^{*}$ & $1.32 \% \%^{* * *}$ & $0.72 \%^{* * *}$ & $-0.08 \%^{* * *}$ \\
\hline Female Executive & $-1.36 \%^{* *}$ & $-0.88 \%^{*}$ & $-0.49 \%^{*}$ & $0.64 \%^{*}$ & $0.54 \%$ & $0.10 \%$ & $0.08 \%$ & $0.21 \%$ \\
\hline Female Non-executive & $-1.96 \% \%^{* * *}$ & $-1.23 \%^{* *}$ & $-0.65 \%^{* *}$ & $0.25 \%$ & $2.48 \%^{*}$ & $1.73 \%^{*}$ & $0.65 \%$ & $0.30 \%$ \\
\hline
\end{tabular}

\section{Panel B1}

\begin{tabular}{|l|c|c|c|c|}
\hline Market Model & \multicolumn{2}{|c|}{ Buy } & \multicolumn{2}{c|}{ Sell } \\
\hline Director & \multicolumn{2}{|c|}{$(-20,-1)$} & \multicolumn{2}{c|}{$(-20,-1)$} \\
\hline & $\mathbf{t}$ & $\mathbf{z}$ & $\mathbf{t}$ & $\mathbf{z}$ \\
\hline EM-NM & -5.63 & -6.11 & -1.17 & -1.06 \\
\hline EM - EF & -2.15 & -2.05 & -1.20 & 1.13 \\
\hline EM- NF & -1.50 & -1.14 & -0.38 & 0.17 \\
\hline NM - EF & -0.76 & -0.79 & 1.41 & 1.35 \\
\hline NM - NF & -0.22 & 0.60 & -0.15 & 0.39 \\
\hline EFB- NF & 0.75 & 1.05 & -1.14 & -0.69 \\
\hline
\end{tabular}

\begin{tabular}{|c|c|c|c|c|c|c|c|c|c|c|c|c|}
\hline \multirow{3}{*}{$\begin{array}{l}\text { Market Model } \\
\text { Director }\end{array}$} & \multicolumn{6}{|c|}{ Buy } & \multicolumn{6}{|c|}{ Sell } \\
\hline & \multicolumn{2}{|c|}{$(-10,-1)$} & \multicolumn{2}{|c|}{$(-5,-1)$} & \multicolumn{2}{|c|}{$(-1,0)$} & \multicolumn{2}{|c|}{$(-10,-1)$} & \multicolumn{2}{|c|}{$(-5,-1)$} & \multicolumn{2}{|c|}{$(-1,0)$} \\
\hline & $\mathbf{t}$ & $z$ & $\mathbf{t}$ & z & $\mathbf{t}$ & $z$ & $\mathbf{t}$ & $z$ & $\mathbf{t}$ & z & $\mathbf{t}$ & $z$ \\
\hline EM - NM & -5.56 & -6.00 & -6.20 & -6.31 & 6.28 & 5.77 & -0.62 & -0.24 & -0.72 & -1.00 & 0.32 & -0.09 \\
\hline EM - EF & -1.63 & -2.02 & -1.20 & -1.08 & 0.32 & 0.32 & 1.25 & 0.85 & -1.39 & -1.77 & -0.98 & -0.60 \\
\hline EM - NF & -1.21 & -1.54 & -1.17 & -0.16 & 3.60 & 3.34 & -0.68 & -0.40 & 1.51 & 0.91 & -0.03 & -0.45 \\
\hline NM - EF & -0.33 & -0.83 & 0.27 & 0.35 & -1.24 & -0.96 & 1.35 & 0.90 & -1.21 & -1.51 & -1.05 & -0.57 \\
\hline NM - NF & 0.49 & 0.10 & 0.01 & 1.72 & 1.55 & 1.81 & -0.54 & -0.36 & 1.61 & 1.04 & -0.08 & -0.41 \\
\hline$E F-N F$ & 0.57 & 0.76 & 0.37 & 0.82 & 1.96 & 1.89 & -1.40 & -0.89 & 2.02 & 1.75 & 0.46 & 0.01 \\
\hline
\end{tabular}


Table 4. Reports the results of the event studies for various post-event windows. Panel A reports the results for the results based on the category of the director. Panel B reports the results of the event study on subsamples formed on the basis of category and gender of the director. Panel B1 reports the results of the pairwise test for difference in CAARS between the various subgroups. The $t$ and $\mathrm{z}$ are the statistics from a t-test and a wilcoxon rank sum test respecively. In Panel B1, EM=Male Executive, NM=Male Non-Executive, EF=Female Executive, $\mathrm{NF}=$ Female Non executive. $\mathrm{EM}=$ Male Executive, $\mathrm{NM}=$ Male Non-Executive, $\mathrm{EF}=\mathrm{Female}$ Executive, $\mathrm{NF}=\mathrm{Female}$ Non executive. The symbols $\$, * * *$, and $* * *$ denote statistical significance at the $0.10,0.05,0.01$ and 0.001 levels, respectively, using a 2 -tailed standardised cross sectional test.

Panel A

\begin{tabular}{|l|c|c|c|c|c|c|c|c|}
\hline Marktet Model & \multicolumn{9}{|c|}{ Buy } & \multicolumn{4}{c|}{ Sell } \\
\hline Director & $\mathbf{( 1 , 2 0 )}$ & $\mathbf{( 1 , 1 0 )}$ & $\mathbf{( 1 , 5 )}$ & $\mathbf{( 0 , 1 )}$ & $\mathbf{( 1 , 2 0 )}$ & $\mathbf{( 1 , 1 0 )}$ & $\mathbf{( 1 , 5 )}$ & $\mathbf{( 0 , 1 )}$ \\
\hline All Directors & $1.55 \%^{* * *}$ & $1.20 \%^{* * *}$ & $0.85 \%^{* * *}$ & $0.85 \%^{* * *}$ & $-1.19 \%^{* * *}$ & $-0.73 \%^{* * *}$ & $-0.39 \%^{* * *}$ & $-0.28 \%^{* * *}$ \\
\hline Executive & $1.70 \%^{* * *}$ & $1.30 \%^{* * *}$ & $0.91 \%^{* * *}$ & $0.92 \%^{* * *}$ & $-1.22 \%^{* * *}$ & $-0.72 \%^{* * *}$ & $-0.41 \%^{* * *}$ & $-0.26 \%^{* * *}$ \\
\hline Non Executive & $1.18 \%^{* * *}$ & $0.91 \%^{* * *}$ & $0.66 \%^{* * *}$ & $0.63 \%^{* * *}$ & $-1.07 \%^{* * *}$ & $-0.66 \%^{* * *}$ & $-0.33 \%^{* * *}$ & $-0.29 \%^{* * *}$ \\
\hline $\mathrm{t}$-test for diff & 4.41 & 4.87 & 4.47 & 6.66 & -0.68 & -0.36 & -0.78 & 0.40 \\
\hline Rank test for diff & 4.60 & 4.79 & 4.37 & 6.24 & -0.92 & -0.67 & -2.30 & -0.11 \\
\hline & & & & & & & & \\
\hline Male & $1.57 \%^{* * *}$ & $1.22 \%^{* * *}$ & $0.87 \%^{* * *}$ & $0.86 \%^{* * *}$ & $-1.20 \%^{* * *}$ & $-0.73 \%^{* * *}$ & $-0.39 \%^{* * *}$ & $-0.28 \%^{* * *}$ \\
\hline Female & $0.88 \%^{* *}$ & $0.53 \%^{*}$ & $0.39 \%^{*}$ & $0.59 \%^{* * *}$ & $-0.89 \%$ & $-0.60 \%$ & $-0.39 \%^{*}$ & $-0.07 \%$ \\
\hline $\mathrm{t}$-test for diff & -2.28 & -3.26 & -3.13 & -2.44 & 0.40 & 0.22 & -0.01 & 0.87 \\
\hline Rank test for diff & -2.26 & -2.96 & -3.41 & -2.37 & 0.92 & 0.87 & 0.72 & 0.72 \\
\hline
\end{tabular}

Panel B

\begin{tabular}{|l|c|c|c|c|c|c|c|c|}
\hline Marktet Model & \multicolumn{5}{|c|}{ Buy } & \multicolumn{4}{c|}{ Sell } \\
\hline Director & $\mathbf{( 1 , 2 0 )}$ & $\mathbf{( 1 , 1 0 )}$ & $\mathbf{( 1 , 5 )}$ & $\mathbf{( 0 , 1 )}$ & $\mathbf{( 1 , 2 0 )}$ & $\mathbf{( 1 , 1 0 )}$ & $\mathbf{( 1 , 5 )}$ & $\mathbf{( 0 , 1 )}$ \\
\hline Male Executive & $1.72 \%^{* * *}$ & $1.32 \%^{* * *}$ & $0.93 \%^{* * *}$ & $0.9 \%^{* * *}$ & $-1.24 \%^{* * *}$ & $-0.75 \%^{* * *}$ & $-0.42^{* * *}$ & $-0.27 \%^{* * *}$ \\
\hline Male Nonexecutive & $1.22 \%^{* * *}$ & $0.94 \%^{* * *}$ & $0.67 \%^{* * *}$ & $0.65 \%^{* * *}$ & $-1.06 \%^{* * *}$ & $-0.64 \%^{* * *}$ & $-0.31 \%^{* * *}$ & $-0.29 \%^{* * *}$ \\
\hline Female Executive & $1.54 \%^{* *}$ & $1.26 \%^{* * *}$ & $0.65 \%^{* *}$ & $0.87 \%^{* * *}$ & $-0.31 \%$ & $0.16 \%$ & $0.21 \%$ & $0.01 \%$ \\
\hline Female Nonexecutive & $0.52 \%$ & $0.11 \%$ & $0.24 \%$ & $0.44 \%^{* *}$ & $-2.18 \%$ & $-2.30 \%$ & $-1.74 \%$ & $-0.25 \%$ \\
\hline
\end{tabular}

Panel B1

\begin{tabular}{|l|c|c|c|c|}
\hline Market Model & \multicolumn{2}{|c|}{ Buy } & \multicolumn{2}{c|}{ Sell } \\
\hline Director & \multicolumn{2}{|c|}{$(\mathbf{1 , 2 0}$} & \multicolumn{2}{c|}{$(\mathbf{1 , 2 0 )}$} \\
\hline & $\mathbf{t}$ & $\mathbf{z}$ & $\mathbf{t}$ & $\mathbf{z}$ \\
\hline EM - NM & 4.16 & 4.33 & -0.84 & -1.06 \\
\hline EM - EF & 0.35 & 0.50 & -0.97 & -1.31 \\
\hline EM - NF & 3.19 & 2.91 & 0.76 & 0.12 \\
\hline NM - EF & -0.65 & -0.45 & -0.77 & -1.05 \\
\hline NM - NF & 1.86 & 1.83 & 0.90 & 0.28 \\
\hline EF - NF & 1.65 & 1.57 & 1.20 & 0.93 \\
\hline
\end{tabular}

\begin{tabular}{|c|c|c|c|c|c|c|c|c|c|c|c|c|}
\hline \multirow{3}{*}{$\begin{array}{l}\text { Market Model } \\
\text { Director }\end{array}$} & \multicolumn{6}{|c|}{ Buy } & \multicolumn{6}{|c|}{ Sell } \\
\hline & \multicolumn{2}{|c|}{$(1,10)$} & \multicolumn{2}{|c|}{$(1,5)$} & \multicolumn{2}{|c|}{$(0,1)$} & \multicolumn{2}{|c|}{$(1,10)$} & \multicolumn{2}{|c|}{$(1,5)$} & \multicolumn{2}{|c|}{$(0,1)$} \\
\hline & $t$ & $z$ & $\mathbf{t}$ & $z$ & $t$ & $z$ & $\mathbf{t}$ & $z$ & $\mathbf{t}$ & $z$ & $t$ & $z$ \\
\hline EM - NM & 4.48 & 4.39 & 4.36 & 4.27 & -0.37 & 0.73 & -0.72 & -1.00 & -1.06 & -2.51 & 0.76 & 0.82 \\
\hline EM - EF & 0.17 & 0.26 & 1.21 & 1.14 & -1.26 & -0.73 & -1.39 & -1.77 & -1.32 & -1.61 & -0.79 & 0.03 \\
\hline EM - NF & 4.67 & 4.01 & 3.45 & 3.87 & 1.08 & 1.45 & 1.51 & 0.91 & 1.71 & 0.74 & -0.91 & -1.02 \\
\hline NM - EF & -0.86 & -0.70 & 0.12 & 0.19 & -1.16 & -0.96 & -1.21 & -1.51 & -1.08 & -1.01 & -0.96 & -0.15 \\
\hline NM - NF & 3.24 & 2.89 & 2.18 & 2.84 & 1.24 & 1.29 & 1.61 & 1.04 & 1.85 & 1.07 & -1.06 & -1.12 \\
\hline$E F-N F$ & 2.60 & 2.41 & 1.34 & 1.74 & 1.71 & 1.66 & 2.02 & 1.75 & 2.16 & 1.30 & -0.19 & -0.86 \\
\hline
\end{tabular}




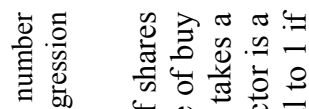

)

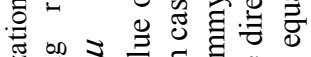

.

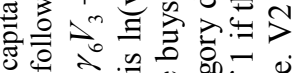

+ $+\frac{2}{0}$ 品

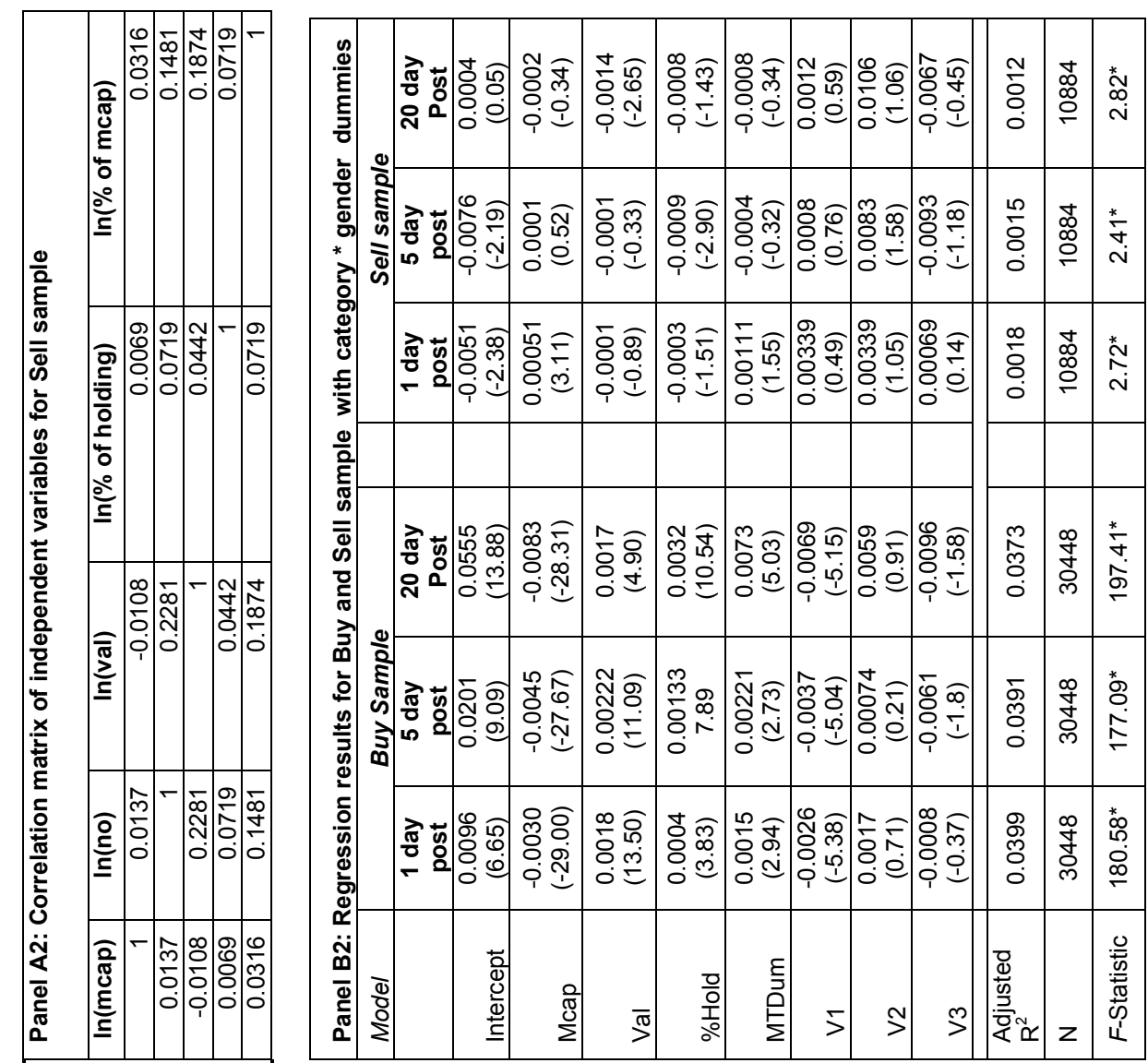

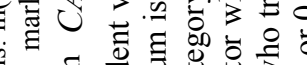

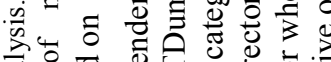

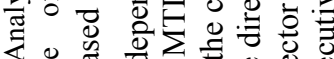

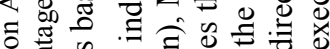

䓎 t.

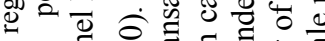

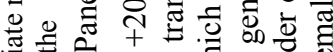

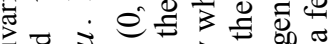

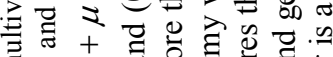
छ ミ ๙

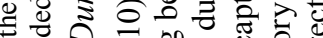

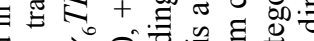

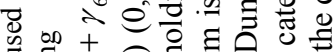

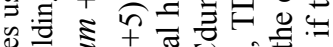
용

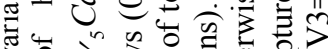

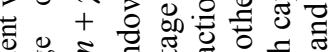
¿ 记 过

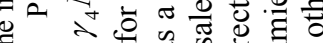
ฮี

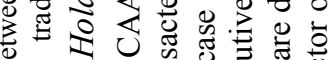

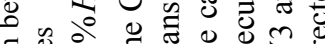
ธี

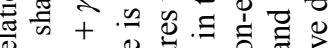
可 N $\Xi \cong+0 \div$

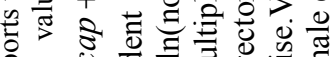
己ृ

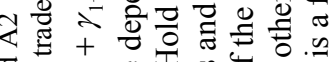
च ठ n ส ข

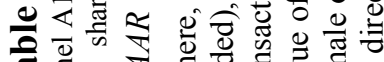

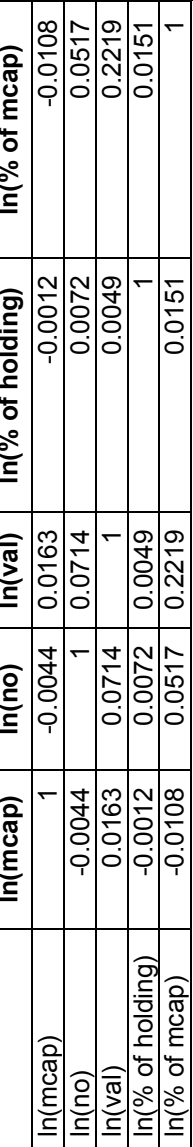

\begin{tabular}{|c|c|c|c|c|c|c|c|c|c|c|c|c|}
\hline & & 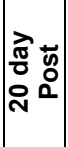 & $\begin{array}{ll} & 0 \\
8 & 0 \\
0 & 0 \\
0 & 0\end{array}$ & 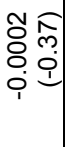 & 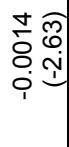 & 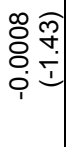 & 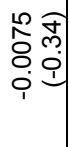 & 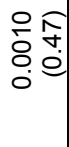 & 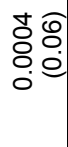 & \begin{tabular}{l}
1 \\
$\bar{\delta}$ \\
\hdashline \\
0
\end{tabular} & \begin{tabular}{l}
$\stackrel{+}{0}$ \\
$\infty$ \\
0 \\
\hdashline
\end{tabular} & $\stackrel{*}{\stackrel{*}{m}}$ \\
\hline 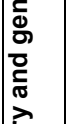 & 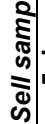 & 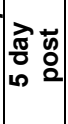 & 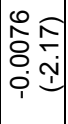 & $\begin{array}{ll}\overline{8} & \widehat{\gamma} \\
8 & + \\
\circ & 0\end{array}$ & 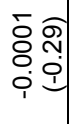 & 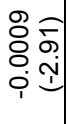 & 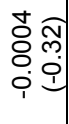 & $\begin{array}{l}0 \\
80 \\
80 \\
0 \\
0\end{array}$ & 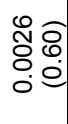 & $\begin{array}{l}\infty \\
\vdots \\
0 \\
0\end{array}$ & \begin{tabular}{l}
$\stackrel{0}{\infty}$ \\
$\infty$ \\
0 \\
\hdashline
\end{tabular} & $\stackrel{*}{N}$ \\
\hline 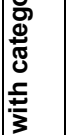 & & 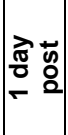 & 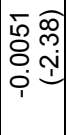 & 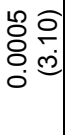 & $\begin{array}{ll}5 & 0 \\
8 & 0 \\
0 & 0 \\
0 & 0 \\
1 & \end{array}$ & 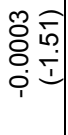 & 它 & 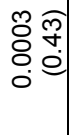 & 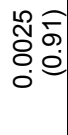 & 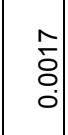 & \begin{tabular}{l}
$\stackrel{0}{0}$ \\
$\infty$ \\
$\circ$ \\
\hdashline
\end{tabular} & $\stackrel{*}{\stackrel{*}{m}}$ \\
\hline$\frac{0}{0}$ & & & & & & & & & & & & \\
\hline $\begin{array}{l}\frac{\omega}{\bar{\sigma}} \\
\overline{\bar{\Phi}} \\
\tilde{\omega} \\
\frac{\partial}{\sigma} \\
\frac{\sigma}{\sigma}\end{array}$ & & $\begin{array}{ll}\vec{\pi} & \\
\frac{\pi}{0} & 0 \\
\text { D } & 0\end{array}$ & 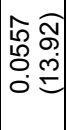 & 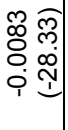 & 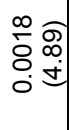 & 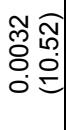 & 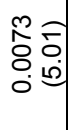 & 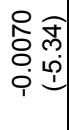 & 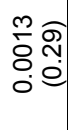 & 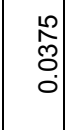 & \begin{tabular}{l}
$\infty$ \\
\multirow{+}{+}{} \\
ర్ల
\end{tabular} & 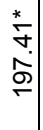 \\
\hline $\begin{array}{l}0 \\
0 \\
\vdots \\
0 \\
0 \\
\frac{0}{5} \\
\frac{1}{5}\end{array}$ & 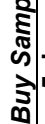 & $\begin{array}{ll}\vec{\partial} \\
0 \\
0 \\
\text { in } \\
0\end{array}$ & 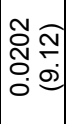 & 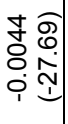 & $\begin{array}{l}\text { స̃ } \\
8 \\
8 \\
0 \\
0\end{array}$ & $\begin{array}{l}m \\
\stackrel{m}{8} \\
8 \\
0 \\
0\end{array}$ & 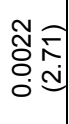 & 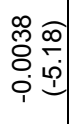 & $\begin{array}{l}\infty \\
80 \\
8 \\
0 \\
0 \\
0 \\
i\end{array}$ & 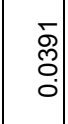 & 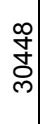 & 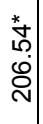 \\
\hline 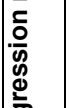 & & 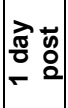 & $\begin{array}{ll}2 & \widehat{0} \\
0 & 0 \\
0 & 0 \\
0 & 0\end{array}$ & 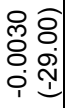 & 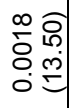 & 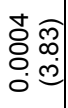 & 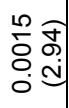 & 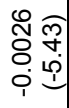 & $\begin{array}{l}\hat{\sigma} \\
\overline{8}\end{array}$ & $\begin{array}{l}\text { ஓ్ } \\
\text { ○. } \\
0 \\
0\end{array}$ & 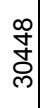 & $\begin{array}{l}* \\
0 \\
0 \\
0 \\
0 \\
\stackrel{0}{N}\end{array}$ \\
\hline 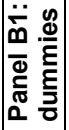 & 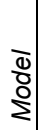 & & 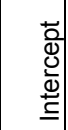 & $\begin{array}{l}\frac{2}{\pi} \\
\stackrel{0}{2} \\
\sum\end{array}$ & $>$ & 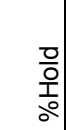 & $\begin{array}{l}\Sigma \\
\vdots \\
\Sigma \\
\Sigma\end{array}$ & 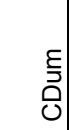 & $\xi$ & 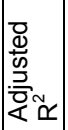 & $z$ & 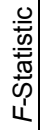 \\
\hline
\end{tabular}


Table 6. The table reports the variance inflation factors for the coefficient of each of the independent variable, to check for multicollinearity for the regression CAAR $=\alpha+\gamma_{1} \mathrm{Mcap}+\gamma_{2} \mathrm{Val}+\gamma_{3} \%$ Hold $+\gamma_{4} \mathrm{MTDum}+\gamma_{5} V_{1}+\gamma_{6} V_{2}+\gamma_{6} V_{3}+\mu$. The VIF is an index which measures how much the variance of a coefficient is increased because of collinearity. the magnitude of multicollinearity by considering the $\operatorname{size}$ of the $V I F\left(\hat{\beta}_{i}\right)$. VIF $>=4$ is an arbitrary but common cut-off criterion for deciding when a given independent variable displays "too much" multicollinearity. Values above 4 suggest a multicollinearity problem.

\begin{tabular}{|c|c|c|c|c|c|c|}
\hline \multirow[t]{2}{*}{ Variable } & \multicolumn{3}{|c|}{ Buy sample } & \multicolumn{3}{|c|}{ Sell Sample } \\
\hline & 1 day post & 5 day post & 20 day post & 1 day post & 5 day post & 20 day post \\
\hline mcap & 1.03 & 1.03 & 1.03 & 1.07 & 1.07 & 1.07 \\
\hline val & 1.36 & 1.36 & 1.36 & 1.41 & 1.41 & 1.41 \\
\hline perofhold & 1.44 & 1.44 & 1.44 & 1.39 & 1.39 & 1.39 \\
\hline dmulpur & 1.14 & 1.14 & 1.14 & 1.12 & 1.12 & 1.12 \\
\hline $\mathrm{v} 1$ & 1.09 & 1.09 & 1.09 & 1.03 & 1.03 & 1.03 \\
\hline \begin{tabular}{|l|}
$\mathrm{v} 2$ \\
\end{tabular} & 1.02 & 1.02 & 1.02 & 1.01 & 1.01 & 1.01 \\
\hline v3 & 1.03 & 1.03 & 1.03 & 1 & 1 & 1 \\
\hline Mean Vif & 1.16 & 1.16 & 1.16 & 1.15 & 1.15 & 1.15 \\
\hline
\end{tabular}

Table 7. The Table reports the linear combinations of the coefficients and their significance for the different category and gender groups, after the following regression CAAR $=\alpha+\gamma_{1}$ Mcap $+\gamma_{2}$ Val $+\gamma_{3} \%$ Hold $+\gamma_{4}$ MTDum $+\gamma_{5} V_{1}+\gamma_{6} V_{2}+\gamma_{6} V_{3}+\mu$. The linear combinations represent the returns made by the different category gender groups. Where, $\mathrm{M}=\mathrm{Male}, \mathrm{F}=\mathrm{Female}, \mathrm{E}=$ Executive, $\mathrm{N}=$ Non executive.

\begin{tabular}{|c|c|c|c|c|c|c|c|c|c|c|c|c|}
\hline & \multicolumn{2}{|c|}{ Buys } & \multicolumn{2}{|c|}{ Sells } & \multicolumn{2}{|c|}{ Buys } & \multicolumn{2}{|c|}{ Sells } & \multicolumn{2}{|c|}{ Buys } & \multicolumn{2}{|c|}{ Sells } \\
\hline & \multicolumn{4}{|c|}{ I day Post CAAR } & \multicolumn{4}{|c|}{5 Day post CAAR } & \multicolumn{4}{|c|}{20 day Post CAAR } \\
\hline & $E$ & $\mathrm{~N}$ & $E$ & $\mathbf{N}$ & $E$ & $\mathbf{N}$ & $E$ & $\mathbf{N}$ & $E$ & $\mathbf{N}$ & $E$ & $\mathbf{N}$ \\
\hline \multirow[b]{3}{*}{ M } & 0.0096 & 0.0069 & -0.0051 & -0.004 & 0.0201 & 0.0164 & -0.0076 & -0.0067 & 0.0555 & 0.0486 & 0.0004 & 0.00159 \\
\hline & -6.65 & -5.04 & $(-2.38)$ & $(-2.20)$ & -9.09 & -7.7 & $(-2.19)$ & $(-1.92)$ & -13.88 & -12.64 & -0.05 & -0.24 \\
\hline & $(p<.0001)$ & $(p<.0001)$ & $(p=0.017)$ & $(p=0.028)$ & $(p<.0001)$ & $(p<.0001)$ & $(p=0.029)$ & $(p=0.055)$ & $(p<.0001)$ & $(p<.0001)$ & $(p=0.957)$ & $(p=0.812)$ \\
\hline \multirow[b]{3}{*}{$\mathbf{F}$} & 0.112 & 0.0087 & -0.0017 & -0.0044 & 0.0208 & 0.014 & 0.0007 & -0.0169 & 0.0614 & 0.046 & 0.011 & -0.0063 \\
\hline & -4.24 & -3.49 & $(-0.460)$ & $(-0.850)$ & -5.12 & -3.65 & -0.011 & $(-2.10)$ & -8.33 & -6.6 & -0.94 & $(-0.390)$ \\
\hline & $(p<.0001)$ & $(p<.0001)$ & $(p=0.649)$ & $(p=0.394)$ & $(p<.0001)$ & $(p<.0001)$ & $(p=0.909)$ & $(p=0.055)$ & $(p<.0001)$ & $(p<.0001)$ & $(p=0.349)$ & $(p=0.694)$ \\
\hline
\end{tabular}

Table 8. The table reports the results for the test for significant difference between the coefficients, after the following regression $C A A R=\alpha+\gamma_{1}$ Mcap $+\gamma_{2}$ Val $+\gamma_{3} \%$ Hold $+\gamma_{4}$ MTDum $+\gamma_{5} V_{1}+\gamma_{6} V_{2}+\gamma_{6} V_{3}+\mu$. Where, EM $=$ Male executive, NM=Male Non executive, $\mathrm{EF}=$ Female Executive, $\mathrm{NF}=$ Female Non executive, $\mathrm{M}=$ Male, $\mathrm{F}=$ Female, $\mathrm{E}=$ Executive, $\mathrm{N}=$ Non executive.

\begin{tabular}{|c|c|c|c|c|c|c|c|}
\hline & & \multicolumn{3}{|c|}{ Buy Sample } & \multicolumn{3}{|c|}{ Sell Sample } \\
\hline & & 1 day post & 5 day post & 20 day post & 1 day post & 5 day post & 20 day post \\
\hline \multirow[t]{2}{*}{ EM - NM } & $\mathbf{F}$ & 28.92 & 25.38 & 26.56 & 0.24 & 0.58 & 0.35 \\
\hline & p val & 0 & 0 & 0 & 0.6261 & 0.4464 & 0.5561 \\
\hline \multirow[t]{2}{*}{ EM - EF } & $\mathbf{F}$ & 0.51 & 0.04 & 0.82 & 1.09 & 2.5 & 1.12 \\
\hline & p val & 0.4751 & 0.8348 & 0.3642 & 0.2958 & 0.1141 & 0.2907 \\
\hline \multirow[t]{2}{*}{ EM - NF } & $\mathbf{F}$ & 0.14 & 3.24 & 2.48 & 0.02 & 1.4 & 0.2 \\
\hline & p val & 0.71 & 0.0718 & 0.1151 & 0.8856 & 0.2362 & 0.6548 \\
\hline \multirow[t]{2}{*}{ NM - EF } & $\mathbf{F}$ & 3.34 & 1.57 & 3.9 & 0.88 & 1.99 & 0.86 \\
\hline & p val & 0.0675 & 0.2106 & 0.0482 & 0.3486 & 0.1582 & 0.3539 \\
\hline \multirow[t]{2}{*}{ NM-NF } & $\mathbf{F}$ & 0.67 & 0.48 & 0.2 & 0.01 & 1.66 & 0.28 \\
\hline & p val & 0.4144 & 0.4876 & 0.6578 & 0.9404 & 0.1976 & 0.597 \\
\hline \multirow[t]{2}{*}{ EF-NF } & $\mathbf{F}$ & 0.62 & 1.98 & 3.12 & 0.22 & 3.52 & 0.93 \\
\hline & p val & 0.4312 & \begin{tabular}{l|l|}
0.1597 \\
\end{tabular} & 0.0772 & 0.6407 & 0.0607 & 0.3339 \\
\hline \multirow{2}{*}{ M - F } & $\mathbf{F}$ & 1.16 & 0.1 & 0.13 & 0.41 & 0.04 & 0.02 \\
\hline & p val & 0.2821 & 0.7485 & 0.7195 & 0.5196 & 0.8494 & 0.8814 \\
\hline \multirow[t]{2}{*}{ E - N } & $F$ & 2.53 & 4.62 & 6.36 & 0.17 & 3.15 & 0.79 \\
\hline & p val & 0.112 & 0.0316 & 0.0116 & 0.6844 & \begin{tabular}{l|l|}
0.0762 \\
\end{tabular} & 0.3731 \\
\hline
\end{tabular}


Table 9 . Reports the results of the event studies using the market model benchmark and the buy and hold abnormal returns for the various pre-event windows . Panel A reports the results for the results based on the category of the director. Panel B reports the results of the event study on subsamples formed on the basis of category and gender of the director. The symbols $\$, *, * *$, and $* * *$ denote statistical significance at the $0.10,0.05,0.01$ and 0.001 levels, respectively, using a 2-tailed standardised cross sectional test.

\begin{tabular}{|c|c|c|c|c|c|c|c|c|}
\hline \multirow[b]{2}{*}{ Director } & \multicolumn{4}{|c|}{ Buy Sample } & \multicolumn{4}{|c|}{ Sell Sample } \\
\hline & $(-20,-1)$ & $(-10,-1)$ & $(-5,-1)$ & $(-1,0)$ & $(-20,-1)$ & $(-10,-1)$ & $(-5,-1)$ & $(-1,0)$ \\
\hline Executive & $-2.34 \% * * *$ & $-1.49 \% * * *$ & $-0.84 \%^{* * *}$ & $0.42 \% * * *$ & $2.12 \%^{* * *}$ & $1.26 \% \%^{* * *}$ & $0.66 \% * * *$ & $-0.01 \%$ \\
\hline Non Executive & $-1.58 \% * * *$ & $-0.92 \%$ *** & $-0.35 \%^{* * *}$ & $0.41 \%$ *** & $2.46 \% *$ & $1.41 \%$ \%** & $0.76 \%$ *** & $-0.06 \%$ \\
\hline Male & $-2.19 \% * * *$ & $-1.37 \% * * *$ & $-0.72 \% * * *$ & $0.43 \% * * *$ & $2.31 \%^{* * *}$ & $1.36 \% * * *$ & $0.73 \% * * *$ & $-0.02 \%$ \\
\hline Female & $-1.53 \% * * *$ & $-0.97 \% * * *$ & $-0.55 \% * * *$ & $0.39 \% * * *$ & $1.37 \%$ & $0.73 \%$ & $0.31 \%$ & $0.25 \%$ \\
\hline & \multicolumn{4}{|c|}{ Buy Sample } & \multicolumn{4}{|c|}{ Sell Sample } \\
\hline Director & $(-20,-1)$ & $(-10,-1)$ & $(-5,-1)$ & $(-1,0)$ & $(-20,-1)$ & $(-10,-1)$ & $(-5,-1)$ & $(-1,0)$ \\
\hline Male Executive & $-2.42 \% * * *$ & $-1.53 \% * * *$ & $-0.86 \% \%^{* * *}$ & $0.40 \%$ *** & $2.13 \%^{* * *}$ & $1.29 \%^{* * * *}$ & $0.67 \%$ *** & $-0.02 \%$ \\
\hline Male Nonexecutive & $-1.58 \% * * *$ & $-0.91 \% * * *$ & $-0.34 \% * * *$ & $0.42 \% * * *$ & $2.44 \%^{* * *}$ & $1.41 \%^{* * *}$ & $0.76 \% \%^{* * * *}$ & $-0.07 \% \$$ \\
\hline Female Executive & $-1.23 \% * * *$ & $-0.76 \% * * *$ & $-0.44 \% * * *$ & $0.63 \% * * *$ & $0.81 \%$ & $0.27 \%$ & $0.16 \%$ & $0.22 \%$ \\
\hline Female Nonexecutive & $-1.69 \% * * *$ & $-1.09 \% * * *$ & $-0.61 \% * * *$ & $0.26 \% *$ & $2.61 \% * *$ & $1.75 \% *$ & $0.65 \%$ & $0.31 \%$ \\
\hline & \multicolumn{4}{|c|}{ Buy Sample } & \multicolumn{4}{|c|}{ Sell Sample } \\
\hline Director & $(1,20)$ & $(1,10)$ & $(1,5)$ & $(0,1)$ & $(\mathbf{1 , 2 0 )}$ & $(1,10)$ & $(1,5)$ & $(0,1)$ \\
\hline Executive & $1.73 \% * * *$ & $1.33 \%^{* * * *}$ & $0.93 \% * * *$ & $0.93 \% * * *$ & $-1.17 \% * * *$ & $-0.68 \% * * *$ & $-0.39 \%$ *** & $-0.26 \% * * *$ \\
\hline Non Executive & $1.22 \% * * *$ & $0.94 \% * * *$ & $0.67 \%$ *** & $0.64 \% * * *$ & $-1.00 \% * * *$ & $-0.64 \% * * *$ & $-0.28 \% * * *$ & $-0.28 \% * * *$ \\
\hline Male & $1.60 \% * * *$ & $1.24 \% * * *$ & $0.88 \% * * *$ & $0.87 \% * * *$ & $-1.14 \% * * *$ & $-0.70 \% * * *$ & $-0.37 \% * * *$ & $-0.28 \% * * *$ \\
\hline Female & $0.91 \% * * *$ & $0.56 \% * * *$ & $0.41 \%$ *** & $0.60 \% * * *$ & $-0.78 \%$ & $-0.53 \%$ & $-0.35 \%$ & $-0.06 \%$ \\
\hline & \multicolumn{4}{|c|}{ Buy Sample } & \multicolumn{4}{|c|}{ Sell Sample } \\
\hline Director & $(1,20)$ & $(1,10)$ & $(1,5)$ & $(0,1)$ & $(1,20)$ & $(1,10)$ & $(1,5)$ & $(0,1)$ \\
\hline Male Executive & $1.75 \% * * *$ & $1.34 \% * * *$ & $0.95 \% * * *$ & $0.93 \% * * *$ & $-1.19 \% * * *$ & $-0.71 \% * * *$ & $-0.40 \% * * *$ & $-0.26 \% * * *$ \\
\hline Male Nonexecutive & $1.26 \% * * *$ & $0.98 \% * * *$ & $0.69 \%$ *** & $0.65 \% * * *$ & $-0.99 \% * * *$ & $-0.61 \% * * *$ & $-0.30 \% * * *$ & $-0.28 \% * * *$ \\
\hline Female Executive & $1.55 \%^{* * *}$ & $1.31 \%^{* * *}$ & $0.66 \%$ *** & $0.87 \%^{* * *}$ & $-0.14 \%$ & $0.23 \%$ & $0.25 \%$ & $0.02 \%$ \\
\hline Female Nonexecutive & $0.55 \%$ & $0.14 \%$ & $0.27 \%$ & $0.45 \%$ *** & $-2.21 \%$ & $-2.22 \% \$$ & $-1.67 \%$ & $-0.24 \%$ \\
\hline
\end{tabular}


Table 10. Reports the results of the event studies using the market adjusted returns benchmark returns for the various pre-event and post event windows. Panel A reports the results for the results based on the category of the director. Panel B reports the results of the event study on subsamples formed on the basis of category and gender of the director. The symbols $\$, * * *$, and *** denote statistical significance at the $0.10,0.05,0.01$ and 0.001 levels, respectively, using a 2-tailed standardised cross sectional test.

\begin{tabular}{|c|c|c|c|c|c|c|c|c|}
\hline & \multicolumn{4}{|c|}{ Buy Sample } & \multicolumn{4}{|c|}{ Sell Sample } \\
\hline Director & Buy $(-20,-1)$ & Buy $(-10,-1)$ & Buy $(-5,-1)$ & Buy(-1,0) & Sell(-20,-1) & Sell(-10,-1) & Sell $(-5,-1)$ & Sell(-1,0) \\
\hline Non Executive & $-2.37 \% * * *$ & $-1.30 \% * * *$ & $-0.55 \% * * *$ & $0.30 \% * * *$ & $2.50 \% * * *$ & $1.47 \%^{* * * *}$ & $0.78 \%$ *** & $-0.06 \%$ \\
\hline \multirow[t]{2}{*}{ Female } & $-1.67 \% * * *$ & $-1.12 \% * * *$ & $-0.68 \% * * *$ & $0.32 \% \$$ & $1.54 \%$ & $0.66 \%$ & $0.27 \%$ & $0.29 \%$ \\
\hline & \multicolumn{4}{|l|}{ Buy Sample } & \multicolumn{4}{|l|}{ Sell Sample } \\
\hline Male Nonexecutive & $-2.43 \% * * *$ & $-1.32 \% * * *$ & $-0.55 \% * * *$ & $0.31 \% * * *$ & $2.48 \%^{* * *}$ & $1.46 \% \%^{* * *}$ & $0.77 \% * * *$ & $-0.07 \%$ \\
\hline Female Executive & $-1.82 \% *$ & $-1.19 \% *$ & $-0.73 \%^{*}$ & $0.53 \% *$ & $0.82 \%$ & $-0.04 \%$ & $-0.05 \%$ & $0.20 \%$ \\
\hline \multirow[t]{2}{*}{ Female Nonexecutive } & $-1.58 \% * *$ & $-1.08 \% * *$ & $-0.65 \% * *$ & $0.19 \%$ & $3.14 \%$ & $2.20 \%$ & $0.98 \%$ & $0.51 \%$ \\
\hline & \multicolumn{4}{|l|}{ Buy Sample } & \multicolumn{4}{|l|}{ Sell Sample } \\
\hline Director & Buy $(1,20)$ & Buy $(\mathbf{1 , 1 0 )}$ & Buy $(1,5)$ & Buy(0,1) & Sell $(1,20)$ & Sell $(1,10)$ & Sell $(1,5)$ & Sell(0,1) \\
\hline \multirow[t]{2}{*}{ Female } & $0.67 \%^{* *}$ & $0.44 \% *$ & $0.32 \% \$$ & $0.53 \% * * *$ & $-0.10 \%$ & $-0.13 \%$ & $-0.07 \%$ & $-0.06 \%$ \\
\hline & \multicolumn{4}{|l|}{ Buy Sample } & \multicolumn{4}{|l|}{ Sell Sample } \\
\hline Director & Buy $(1,20)$ & Buy $(\mathbf{1 , 1 0 )}$ & Buy $(1,5)$ & Buy(0,1) & Sell $(1,20)$ & Sell $(1,10)$ & Sell $(1,5)$ & Sell(0,1) \\
\hline Male Executive & $0.45 \%$ *** & $0.67 \%^{* * *}$ & $0.61 \%$ *** & $0.78 \% * * *$ & $-0.73 \% * * *$ & $-0.52 \% * * *$ & $-0.33 \% * * *$ & $-0.23 \% \%^{* * *}$ \\
\hline Male Nonexecutive & $0.34 \%$ *** & $0.48 \%$ *** & $0.42 \%$ *** & $0.54 \% * * *$ & $-0.75 \% \%^{* *}$ & $-0.48 \% * *$ & $-0.23 \% \$$ & $-0.27 \%^{* * *}$ \\
\hline Female Executive & $0.85 \%^{* *}$ & $0.86 \%$ ** & $0.45 \% *$ & $0.71 \% \%^{* *}$ & $0.37 \%$ & $0.59 \%$ & $0.51 \%$ & $0.09 \%$ \\
\hline Female Nonexecutive & $0.58 \% \$$ & $0.20 \%$ & $0.19 \%$ & $0.43 \% * *$ & $-1.16 \%$ & $-1.75 \%$ & $-1.34 \%$ & $-0.37 \%$ \\
\hline
\end{tabular}

